\title{
Tectonic and sedimentary inheritance on the structural framework of Provence (SE France): Importance of the Salon-Cavaillon fault.
}

\author{
Stéphane Molliex ${ }^{1 *}$, Olivier Bellier ${ }^{1}$, Monique Terrier $^{2}$, Juliette Lamarche ${ }^{3}$, Guillaume \\ Martelet $^{2}$, Nicolas Espurt ${ }^{1}$ \\ 1- CEREGE, Centre Européen de Recherche et d'Enseignement de Géosciences de l'Environnement, UMR \\ 6635, Aix-Marseille Université, Europôle de l'Arbois, BP80, 13545 Aix-en-Provence cedex 04 \\ 2- Bureau de Recherche Géologique et Minière, 3 avenue Claude-Guillemin - BP 36009 - 45060 Orléans \\ Cedex 2 \\ 3- Laboratoire de Géologie des Systèmes et Réservoirs Carbonatés, EA 4234 Université de Provence, case \\ 67, 3, place Victor Hugo, 13331 Marseille cedex 03 \\ *Corresponding author: molliex@ cerege.fr
}

Published in 2011 in Tectonophysics, 501, p. 1-16, doi: 10.1016/j.tecto.2010.09.008

\begin{abstract}
Using field data, balanced cross-sections, gravity and reprocessed seismic reflection data, a detailed structural study has been realized on the Salon-Cavaillon fault (SCF) area, in Provence region (SE France). This fault separates two main ridges (the Alpilles to the west and the Luberon to the east). Field data and balanced cross-sections allow us to characterize the present-day structures and the post-Oligocene deformation that significantly differ on either sides of the SCF. Our structural study shows a post-Oligocene southward displacement of the structures on the two sides of the SCF. The Luberon ridge is a fault propagation-fold developed on a S-verging ramp. The anticline is bent as a drag fold in the vicinity of the dextral strike-slip SCF. The Alpilles ridge is a less developed fault propagation fold. Its eastern termination was affected by a counter-clockwise rigid block rotation around a vertical axis. The differences between the two ridges in terms of structural architecture are explained by the deep geometry of their ramp, inherited from the Late Cretaceous to Middle Eocene Pyrenean tectonic phase. The décollement level is shallow to the western side of the SCF $(2-3 \mathrm{~km})$, probably in Lower Cretaceous or Upper Jurassic marls, than in the eastern side, the fault is rooted in Triassic layers at a depth $>5 \mathrm{~km}$. The deep rooting favoured a large-scale fault propagation type of folding, whereas shallow-seated rooting favoured a small-scale fault propagation type of folding and block rotations.

To image the sub-surface structures to the west of the SCF, we also included gravity data and reprocessed seismic reflection. It allows us to refine the regional tectonic framework and to detect several hidden E-trending S-verging folds. The main shortening episode in Provence occurred during the Pyrenean phase, with $65 \%$ of the total shortening to the east of the SCF and $95 \%$ to the west. From the Miocene to present, Alpine shortening decreases strongly to the West of the SCF (less than $400 \mathrm{~m}$ against $2 \mathrm{~km}$ to the East), providing evidence for the major role of the SCF in the transfer of the south-directed Alpine deformation.
\end{abstract}

\section{Introduction}

During the growth of an orogen, the sedimentation in the foreland is generally heterogeneous in terms of lithology and thickness. It is often affected by motion along inherited basement faults (e.g., DeCelles and Giles, 1996). These syn-sedimentary tectonics result in 
anisotropic domains where the sedimentary and tectonic inheritance plays an important role in the syn- to post-orogenic deformation.

The study area is located in the SE France basin that is in a foreland position with respect to the Pyrenees and the Alps (fig.1). This area has been the site of numerous studies and the different tectonic phases are well-known (e.g. Bertrand, 1899, Corroy et al., 1964, Guieu, 1968, Clauzon, 1984, Tempier, 1987, Philip et al., 1987, Champion et al., 2000, Baroux et al., 2001). Tectonic and sedimentary inheritances played a major role in the Cenozoic deformations of Provence. These inheritances are due to the irregular geometries of the Mesozoic basins (Baudrimont and Dubois, 1977, Ménard 1980, Debrand-Passard et al., 1984) and to deep-seated faults of Late Hercynian age, especially NNE-trending strike-slip faults such as the Middle Durance fault (MDF), the Nîmes fault (NF) or the Salon-Cavaillon fault (SCF) (Arthaud and Matte, 1975, Roure and Colletta, 1996), (Fig.1).

A recent reinterpretation of a seismic reflection profile across western Provence (Terrier et al., 2008), shows that the main thrusts located between the MDF and the SCF have a southward vergency while $\mathrm{N}$-verging ramp anticlines are located to the east of the MDF and to the west of the SCF. These observations imply that the zone between the MDF and the SCF is decoupled from the rest of Provence and that these two faults could be considered as principal transfer zones of deformation and major structures in the regional tectonic model. Transfer zones of deformation in fold and thrust belts are complex zones described both in the field and experimentally in many places (e.g. Coletta et al., 1991; Calassou et al., 1993). In Provence, several studies of the of the NPCB's (the MDF or the NF) border faults have been conducted ( e.g. Rousset, 1978; Terrier and Lenotre, 1989; Roure and Colletta, 1996; Benedicto et al., 1996; Baroux, 2000; Schlupp et al., 2001; Guignard et al, 2005; Cushing et al., 2008) , but few specific investigations have addressed the SCF although it is considered to be an active structure (REGINE group, 1991; Terrier, 1991; Amorèse et al., 2009). .Therefore, it is important to constrain the geometry and kinematics of this fault.

In order to reach this goal, we performed a structural study based on a multidisciplinary approach. We used field data, balanced cross-sections, seismic reflection data and gravity data to constrain the geometry of E-W ridges either side of the SCF (particularly the Alpilles and the Luberon structures) in order to characterize the deformation pattern around this fault and evaluate its role in the tectonic evolution of Provence.

\section{1- Geological setting}

The Provence region is located in the foreland domain of the Pyrenean and Alpine mountain belts (fig.1). It is affected by E-Wramp anticlines and N- to NE-trending strike-slip faults inherited from the later stages of the Hercynian orogeny and reactivated during Mesozoic and Cenozoic times (Villeger and Andrieux, 1987; Séranne, 1999, Champion et al., 2000).

The present-day structural pattern of Provence results from several superimposed tectonic stages linked to Pyrenean and Alpine orogenies and to Mediterranean geodynamics. Hereafter, we will briefly summarize the main tectonic events that affected the Provence area.

\section{1-1) Geodynamic history}

During the Tethysian rifting (Triassic to Late Jurassic), the Provence area corresponds to the NW-trending margin of the Alpine Tethys (Lemoine and Trümpy, 1987, Stampfli and Borel, 2002). Shelf basins, such as the SE France Basin took place following reactivation of Late Hercynian faults during the opening of the Liguruan Sea (Lemoine, 1984). The extension 
continue during the Early Cretaceous. It results from the development of a thick carbonate platfrom in Provence (De Graciansky and Lemoine, 1988; Hibsch et al., 1992; Masse et al., 2009).

After the Early Cretaceous, the formation of the Durance isthmus (Gignoux, 1925), resulted in a Late Cretaceous unconformity and the widespread development of bauxite.

At the end of the Cretaceous, Europe and Africa began to converge (Dercourt et al., 1986; Dewey et al., 1989; Rosenbaum et al., 2002; Stampfli and Borel, 2002, Sibuet et al., 2004). The collision between the Iberian and western European blocks led to the uplift of the Pyrenees and the Catalan ranges (Mattauer, 1968, Roure and Choukroune, 1998, Fitzgerald et al., 1999). In Provence, two tectonic phases occurred: first, a large-scale folding (Corroy et al., 1964; Leleu et al., 2009) at the end of Cretaceous; second, a Middle Eocene, Pyrenean fold-and-thrust responsible for N-verging folds and thrusts (e.g. Bertrand, 1999; Haug, 1925; Guieu, 1968; Tempier, 1987).

During the Oligocene, the E-W extension in the West-European platform led to the formation of the West-European rift system (Bergerat, 1987; Le Pichon et al., 1988; Hippolyte et al., 1991; Ziegler, 1992; Séranne, 1999). In Provence, this extension is expressed as grabens, locally deeper than $3000 \mathrm{~m}$, developed during the Early Oligocene (Bergerat, 1987; Villeger and Andrieux, 1987; Hippolyte et al., 1993).

A second extensional phase occurred during the Late Oligocene and the Early Miocene, when the Liguro-Provençal basin opened between Provence and the Corso-Sarde block (Rehault et al., 1984; Hippolyte et al., 1993; Mauffret and Gorini, 1996; Roca et al., 1999; Gattacceca et al., 2007). It caused marine transgressions, erosional surfaces and marine molasse deposits in Provence (Demarck, 1970; Besson et al., 2005). From the Late Oligocene to the Middle Miocene, the Alpine front propagated toward the SW in SE France, reactivating Pyrenean structures essentially in western Provence where S-verging ramp anticlines developed. The N-to-NE trending faults were reactivated as strike-slip faults. The main Miocene Alpine fold-and-thrust deformation occurred during the Tortonian (Clauzon, 1984; Clauzon et al., submitted) but may have started since Langhian (Villeger, 1984; Blès et Gros, 1991).

A change in the stress pattern occured between the Late Miocene and the Quaternary characterised by a shift from a compressionnal to a transpressional regime in Provence (Baroux et al., 2001; Cushing et al., 2008). It may be related to a change in Alpine stress patterns during the Pliocene, the perpendicular to the range extension in the inner Alps caused compression in the front of the belt and in its foreland (Champagnac et al., 2004; Sue et al., 2007). The Provence area is currently considered to be a moderate seismic domain, but several destructive events have occurred during the past few centuries (Levret et al. 1994; Lambert et al., 1996). Furthermore, many studies display evidences for Quaternary faulting revealed by paleoseismological or structural studies (Combes et al., 1993 ; Sébrier et al., 1997; Hippolyte and Dumont, 2000 ; Dutour et al., 2002; Guignard et al., 2005; Chardon et al., 2005). Other evidence for Quaternary deformation such as geomorphic anomalies or levelling measures were also reported, particularly along the main faults of Western Provence (Terrier, 1991; Baize et al., 2002). Regarding the present-day deformation, the compilation of focal mechanisms of earthquakes suggests that important local variations of stress pattern exist in Provence, due to different sources of stresses and to deviations near major strike-slip faults (Baroux et al., 2001).

\section{1-2) Structural pattern}

The Provence region can be subdivided into two parts (Fig. 1): eastern and western Provence. The two domains are separated by the N20 ${ }^{\circ}$ E-trending MDF (Fig.1), which corresponds to the eastern border of the Mesozoic SE France basin (Baudrimont et Dubois, 
1977). The western border of this basin is the $\mathrm{N} 40^{\circ} \mathrm{E}$-trending Cevennes fault (CF) (Fig. 1), which is the boundary with the Hercynian "Massif Central" domain.

Eastern Provence corresponds to the eastern border of the Mesozoic shelf basin. The sedimentary cover is only $2-\mathrm{km}$ thick. Most of the structures are N-S ramp anticlines. Mesozoic marine deposits are covered in the northern part by Cenozoic continental deposits at the front of the Alpine belt (Valensole Plateau, Fig.1).

Western Provence comprises a thick $(5-10 \mathrm{~km})$ Mesozoic and Cenozoic sedimentary cover deposited in shelf basin conditions. Most of the tectonic structures are S-verging ramp anticlines. This part of the Provence has been described as "North Provence Cover Block" (NPCB) (e.g. Villeger and Andrieux, 1987). The NPCB is a $100 \mathrm{~km}$ wide quadrilateral defined as the part of Provence where Miocene deformation occurred. It is delimited to the west by the NF, to the north by the Ventoux-Lure thrust and to the east by the MDF (Fig. 1). The SCF is another main N-S fault that crosses the NPCB in its middle part. Several ridges of the NPCB are bounded by the SCF: Luberon, Alpilles, Costes or La Fare ridges (Fig.1 and Fig.2).

Geophysical studies provide evidence for differences in sedimentary cover thickness in the NPCB (Ménard, 1980) (Fig.2). This is confirmed by sedimentary studies that show variability in facies and subsidence rates into the NPCB (Baudrimont and Dubois, 1977, Debrand-Passard et al., 1984). The base of the sedimentary cover comprises a thick evaporitic Triassic layer (more than $1 \mathrm{~km}$ ) which forms a main décollement level (e.g. Guieu, 1968; Tempier, 1987; Benedicto et al., 1996; Champion et al., 2000). Other potential shallower décollement levels also exist in Middle Jurassic or Lower Cretaceous marls.

\section{2) Characterisation of the deformation in the SCF zone}

\section{2-1) Architecture of the SCF}

The SCF is a main structure of the NPCB. It is an $80 \mathrm{~km}$ long fault zone that delimits several E-W ridges: the Alpilles to the west, the Luberon, Costes and La Fare ridges to the east. The SCF is considered to be a vertical dextral strike-slip fault (Combes, 1984; Ritz, 1991). Three different domains of the SCF can be described (Fig. 2):

(i) To the north, the SCF is segmented. It goes through the Vaucluse Plateau and can be followed northward to the Ventoux-Lure N-verging thrust. The northernmost extension of the SCF is marked by the presence of the Sault graben, which separate the Ventoux and the Lure ridge. The SCF plays the role of a transfer fault between the Ventoux thrust to the west and the Lure thrust to the east (Fig.2).

(ii) In its middle part, the SCF is probably composed of a single segment. The fault outcrops to the south of Vaucluse Plateau, where Miocene continental deposits of the Carpentras basin are in tectonic contact with Cretaceous limestone of the Vaucluse Plateau. Here, the SCF lies down to the west. Further south, the SCF separates the Alpilles and the Luberon ridges, but does not outcrops in this area.

(iii) The southern part of the SCF is covered by Quaternary deposits. Therefore, the location and geometry of the SCF are estimated using geophysical and borehole data. The southern part of the SCF is composed of at least two parallel segments which delimited an Oligocene graben deduced from borehole information. The southern termination of the fault is unknown. It probably does not continue offshore (Mauffet and Gorini, 1996). 


\section{2-2) Mesozoic sedimentation heterogeneities on either side of the SCF}

The sedimentary cover has been compared on either side of the SCF, using surface mapping, boreholes data, and regional syntheses (Baudrimont and Dubois, 1977; DebrandPassard et al. 1984) (fig.3). The thickness of the sedimentary cover interpreted from geophysical data (Ménard, 1980) (fig.2) shows two high subsidence zones (with more than 10 km-thick sedimentary cover) in the NPCB: Carpentras basin to the NW (Fig.2) and the La Fare basin to the SE (Fig. 2). The SCF separates these two basins.

In the NPCB, the Jurassic to Early Cretaceous series are characterized by an alternation of marine marls and limestones. The Provence region was emerged from the end of Early Cretaceous to the Late Oligocene (Baudrimont and Dubois, 1977; Debrand-Passard et al., 1984) . During this period, sedimentation is characterized by lacustrine limestone and conglomerates. The Miocene is marked by a succession of three regional marine transgressions and the deposition of sand and molasses (Demarcq, 1970; Besson et al., 2005).

In the Alpilles, Late Jurassic limestones are less developed ( 400 $\mathrm{m})$ than marls of Early and Middle Jurassic (> 1000 m) (Fig. 3). For Early Cretaceous times, while the thickness of sediments was moderate during Berriasian and Valanginian $(<400 \mathrm{~m})$, the deposition of more than $1500 \mathrm{~m}$ of marly limestone occurred during the Hauterivian. The thickness of the Late Cretaceous to Eocene sediments could reach up to $500 \mathrm{~m}$, while the Miocene sands and molassesreach up to $200 \mathrm{~m}$ to the north of the Alpilles.

In the Luberon, Late Jurassic limestones are thicker $(\sim 80 \mathrm{~m})$ than in the Alpilles (Fig. 3), while the thickness of Early and Middle Jurassic marls is less than $1500 \mathrm{~m}$. Berriasian and Valanginian deposits $(\sim 1500 \mathrm{~m})$ are thicker than the Hauterivian series $(\sim 1000 \mathrm{~m})$. Thickness of Cenozoic sedimentary cover is almost the same as for the Alpilles.

It is possible to highlight that the Late Jurassic and the Early Neocomian series are thinner in the Alpilles than in the Luberon. On the contrary, the Hauterivian series are thicker in the Alpilles (more than $1500 \mathrm{~m}$ ) than in the Luberon $(\sim 1000 \mathrm{~m})$. For older formations, important variations in subsidence could exist, implying a permanent difference of subsidence rates within the NPCB during the Mesozoic (Baudrimont et Dubois, 1977; Debrand-Passard et al., 1984). On either side, the SCF plays a major role in local sedimentation differences even if it is a less important structure than the MDF or the Ventoux-Lure domain which play a regional role in the Mesozoic sedimentation.

\section{2-3) Structural study of the Luberon and Alpilles ridges}

To constrain the geometry and the chronology of deformations in the SCF area, we studied the relation between the SCF, the Alpilles and the Luberon ridges (Fig.4). Surface data, regional mapping (Germain et al., 1966; Gouvernet et al., 1968; Catzigras et al., 1975; 1977), aerial and satellite images, boreholes description and seismic reflection data were integrated to construct two balanced cross-section of about $11 \mathrm{~km}$ long across the two ridges. The reconstruction was realized according to classic tectonic thrust concepts (Dahlstrom, 1969; Boyer and Elliott, 1982; Elliott, 1983; Woodward et al., 1985; Shaw et al., 1999). The crosssections were balanced on the basis of bed length and thickness conservation, and flexural-slip algorithm (e.g., Ramsay and Huber, 1987). The cross sections were restored at the top of the Early Cretaceous deposits (top of Barremian), assuming that they were horizontal at the time of deposition, and pinned to local pin lines to the south (Fig.5 and Fig.6). In addition, a detailed structural study allows us to better characterize the Miocene part of the deformation (Fig. 4). 


\section{2-3-1) The Luberon ridge}

The Luberon is an E-W ridge extending from the MDF to the SCF (Fig.1). It reaches nearly $1100 \mathrm{~m}$ a.s.l. at its highest point in the eastern part. The ridge is composed of two parts separated by a $\mathrm{N} 60^{\circ}$ E-trending oblique lateral ramp (oblique reverse left-lateral strike-slip). Only the western part of this ridge is considered in this paper.

The range is formed by an E-W S-verging ramp anticline overthrusting an Eocene and Miocene continental foreland basin (Fig. 4). The balanced cross-section shows that the structure of the western Luberon ridge (Fig. 5) corresponds to a S-verging breakthrough faultpropagation fold. The thrust system consists of two main thrust faults. The lower southern thrust cuts through and deforms the Cenozoic strata of the southern Durance syncline. This thrust dips $\sim 30^{\circ}$ to the north as constrained by observations in the Luberon1 borehole. The northern upper thrust cuts the hangingwall ramp anticline and connects downward to the lower thrust. The depth of the décollement level is controlled by the position of the Apt syncline axis marking the termination of the northern anticline flank. The décollement level is $\sim 4.5 \mathrm{~km}$ deep, probably located at the Triassic- Jurassic interface. The main thrust is the southern branch and affects the southern hinge of the anticline. A large part of the deformation along this fault occurred during the Late Cretaceous to Eocene Pyrenean phase, as indicated by Late Cretaceous to Eocene syntectonic sedimentation in the Luberon foreland (Goguel, 1932). The restoration of the cross-section shows a total horizontal shortening across the Luberon ridge of $\sim 2900$ m (Fig.5).

Langhian deposits folded and faulted in the fold attest to a shortening Alpine reactivation. Against the $\mathrm{SCF}$, the fold axis is bent up to reach a $\mathrm{N} 45^{\circ} \mathrm{E}$ strike (Fig.4) as a drag fold termination along a dextral strike-slip fault. The northern flank of the Luberon, including the Miocene deposits of the Apt syncline, is affected by this bend, whose drag folding has been attributed a post-Langhian age. The western termination of the Luberon ridge is affected by normal $\mathrm{N}$ to NE-trending faults. The periclinal termination of Luberon is observed to the West of the SCF, in the St-Pierre hill, to the west of Cavaillon city (fig.4). The Luberon ridge is thus truncated by $\mathrm{a} 10^{\circ} \mathrm{E}$ graben associated with the SCF system. The main escarpment of the western Luberon is a normal fault that affects Burdigalian, but which is sealed by Langhian deposits. So, this escarpment corresponds to the geomorphic evidence for the Oligocene normal fault of the SCF until the end of Burdigalian. This observation allows us to constrain the change in tectonic regime from Oligocene to Burdigalian extension to alpine compression at the Burdigalian-Langhian transition (16 Ma). A Miocene marine abrasion surface constitutes the top of the ridge at an elevation of about $700 \mathrm{~m}$ a.s.l. (fig.5 and fig.7c) (Goguel, 1932; Champion et al., 2000). The age of this surface could be Burdigalian or Langhian (Besson, 2005). The same surface is visible south of the northern thrust at $400 \mathrm{~m}$ a.s.l. (fig.5 and fig.7c). The deformation of the surface indicates that the cumulative deformation on the northern fault was completed during the Alpine phase (after $16 \mathrm{Ma}$ ). Part of the deformation along the southern thrust was also been achieved after $16 \mathrm{Ma}$, as shown by the high elevation of the Miocene marine abrasion surface on the southern flank (400 m).

\section{2-3-2) The Alpilles ridge}

The Alpilles ridge corresponds to an E-W range with a moderate elevation ( $\sim 500 \mathrm{~m})$. Two structural domains are identified. They are separated by a NW-SE right lateral strike-slip fault zone (Fig.4 and Fig.7a). To the SE, this fault system is connected to a fold-and-thrust system (Monts Opies , Fig.4). This thrust system is responsible for the exposure of Jurassic formations in the Alpilles. 
The western unit is a $\mathrm{N} 100^{\circ}$ E-trending S-verging ramp anticline (Alpilles anticline, Fig.4). The northern part of the western Alpilles structure corresponds to a S-verging fault-bend anticline overthrusting the marine Miocene series of the Baux de Provence syncline (Fig.4 and Fig.6). At depth, the backlimb of the anticline shows Cretaceous strata dipping $\sim 30^{\circ}$ northward. At the surface, these strata dip up to $70^{\circ}$ to the north and are deformed by a back-thrust dipping $15^{\circ}$ southward. (Fig.6). The décollement surface level is constrained by the hinge of the northern syncline. The construction of the balanced cross-section implies that the décollement surface is located at about 2-km depth, probably at the Valanginian-Hauterivian series interface. To the south of the western Alpilles, two S-verging fault-propagation folds affect the foreland. The dip of the ramps of the two folds is constrained by the dip of their northern flank to the surface. It is about $30^{\circ}$ northward. The geometry of these folds is controlled by a ramp which is connected at a deeper décollement level, probably in the Middle Jurassic marls-Late Jurassic limestones interface, at $\sim 2.7-\mathrm{km}$ deep (Fig.6). The emersion of the Alpilles anticline began before the Late Cretaceous as shown by the low-angle unconformity of the Aptian bauxite above the lower Cretaceous series (Gignoux, 1925; Rousset, 1975). An angular shear within the Late Jurassic series has been necessary to balance the two frontal structures (Fig. 6). This may be related to the ductile behaviour of the Late Jurassic series (shales). Our model propose that the shallowest décollement level connects further north to the deepest décollement level. The restoration of the cross-section shows a total horizontal shortening of $\sim 4200 \mathrm{~m}$ (Fig.6).

The eastern unit is a NW-dipping homocline truncated by a nearly-horizontal Miocene abrasion surface. The eastern unit is cut by $\mathrm{N} 45^{\circ} \mathrm{E}$-trending faults (Fig.4). The change of the orientation of the bedding and faults in this area can be explained by a counter-clockwise rotation of the eastern part around a vertical axis. This rotation is accommodated by displacement along the $\mathrm{N}$ to $\mathrm{NW}$-trending dextral strike-slip fault zone which separates the two units (Fig.4 and Fig.7a).

The unconformity and the weak deformation of Miocene strata in the Alpilles range (Goguel, 1944) shows that the main shortening occurred before the Miocene, probably during the Late Cretaceous to Eocene Pyrenean phase (Fig. 6 and Fig.7b). The Alpine phase is only responsible for a slight reactivation of the main Alpilles anticline. Miocene deposits outcrop poorly and are less deformed than in the Luberon area. The Miocene abrasion surface has an average elevation of $250 \mathrm{~m}$ in the eastern unit. This surface is flat, not deformed, and preserved in several places in Provence at this elevation (Champion et al., 2000). Consequently, the present elevation probably corresponds to the elevation of its setting. In the western part, the same surface is preserved at an elevation of $380 \mathrm{~m}$. Thus, the Alpine deformation is responsible for part of the shortening in the western side, whereas no significant shortening occurred in the eastern part. So, the displacement along the dextral strike-slip fault zone that separates the two sides of the Alpilles range results from the Alpine compression.

The termination of the range near the SCF is cut by a 150 m-high escarpment (Fig.4). This escarpment affects Late Eocene deposits. It was probably formed by normal faulting along the SCF system during the Oligocene extension phase, as for the eastern termination of the Luberon ridge.

\section{2-4) Sub-surface data}

Because of the large development of Quaternary deposits, covering Mesozoic and Cenozoic structures, sub-surface data are necessary to study the area located to the west of the SCF. We reinterpreted 2 seismic profiles reprocessed in 2005 from original 1982 field recordings (Fig. 8 and Fig.9). Depths proposed from two-way times are calculated by the time- 
to-depth model of Cushing et al. (2008). For interpretations, the reflectors were calibrated using available deep boreholes. We also used available geological maps (Germain et al., 1966; Gouvernet et al., 1968; Catzigras et al., 1975; 1977), completed by field observations. Then, we used gravity data in order to extrapolate in three dimensions the extension of the structures viewed in cross-sections on seismic profiles (Fig.10).

\section{2-4-1) Seismic reflexion data}

\section{2-4-1-1) Profile 82SE4D across the SCF and the south of the Alpilles ridge}

The profile 82SE4D is $41 \mathrm{~km}$ long and strikes NW-SE (Fig.1 and Fig.8). It crosses the southern part of the Alpilles ridge, through the Crau plain and down to the north of the Nerthe range. This profile should cut the supposed trace of SCF in its southern part (Fig.8). The Istres borehole, which crosses the sedimentary cover from the Cretaceous to the Lias (location in Fig.2) constrains the position of reflectors in the southeastern part..

A Tertiary erosion surface, characterized by an unconformity and deep incision features at the base of CDP 840, 1010 and 1350 is visible in the southern part of the profile (Fig.8). Part of this incision may result from the Messinian Salinity Crisis. Another part of the incision could result from the erosion of the northern margin of the Liguro-Provençal basin during its Oligocene formation (Oudet, 2008). The Upper Jurassic is characterized by well-contrasted reflectors. The Istres boreholecrosses a N-S hidden ramp anticline (Istres anticline; Fig.8). This structure does not affect Oligo-Miocene layers. The Anelier ridge, located at CDP 600 (Fig. 8) is a $\mathrm{N}$-verging thrust system with a décollement level rooted into Middle Jurassic layers. Its northern termination corresponds to the Mouriès klippe (Rousset, 1974), visible at the base of CDP 370 (Fig. 8). This structure does not affect Oligo-Miocene sediments either. Thus there is no evidence of alpine reactivation further south of the Alpilles ridge. The north of the seismic line corresponds to the southern part of the Alpilles range. The low resolution does not allows us to propose any accurate interpretation.

To the southeast of the profile, sedimentary thickness reaches more than 5 twt (s) (about $11 \mathrm{~km}$ depth) (Fig.8). The top of the basement is interpreted from slightly stronger reflection features and intersections with line 82SE4C (Fig.9). It is deeper to the south (more than 5 twt) than to the north (4 twt (s)). This deepening is located at the base of the SCF supposed trace ( CDP 1300; Fig.8). A normal crustal fault was probably responsible for a down throw of the basement during Mesozoic sedimentation. This normal down throw may be related to the SCF, but also to the Istres fold and thrust. The supposed western branch of the SCF should be located on the surface between CDP 1000 and CDP 1200, but the seismic profile does not show any evidence for a such fault in the sedimentary cover (the reflectors being continuous). The high quality of the southern part of the profile, which nearly reach the Nerthe range constrain the termination of the SCF. Indeed, the SCF may not be present to the south of the Istres borehole, suggesting that the termination of the SCF is located North of this profile.

\section{2-4-1-2 Profile 82SE4C: Across Alpilles ridge and the northern structures}

The 82SE4C seismic profile strikes NNE-SSW (Fig.1). It is 45-km long. It crosses 82SE4D line to the South at CDP 1800 (Fig.9). It extends from the southern Carpentras basin, through the Durance plain and across the Alpilles ridge and its foreland, nearly reaching the Anelier thrust (Fig.9). The resolution of the line does not allows us to propose an interpretation for reflectors under the Middle Jurassic. 
The southern border of the Oligocene Carpentras basin comprises tilted blocks along Sdipping normal faults (Fig.9). Thickness of the Oligocene series can reach $600 \mathrm{~m}$ (0.4 twt (s)). Three S-verging hidden ramp anticlines can be distinguished in the central part of the profile (Caumont anticline, CDP 800; Chateaurenard anticline, CDP 970; St Remy anticline, CDP 1340; Fig.9). These folds are about $3 \mathrm{~km}$ wide and are less developed than the Alpilles anticline (CDP 1600; Fig.9). The interface between the Upper and Middle Jurassic layers is constrained by the Pernes borehole (location on Fig.2). It is located at about 1.5 twt (s) (3900 m); it seems undeformed by the faults that affect overlying folds. Consequently, the décollement level is shallower than 1.5 twt (s) $(3900 \mathrm{~m})$, likely into the Early Cretaceous or Late Jurassic series.

The Alpilles ridge is a N-S ramp anticline with a higher amplitude than the folds located further north (4.5 km wide) (Fig.9). The décollement level seems to be relatively shallow, about 1.5 twt (s) $(3900 \mathrm{~m})$. Two folds in front of the main thrusts are related to the Alpilles thrust system. Comparisons with profile $82 \mathrm{SE} 4 \mathrm{~B}$; (this seismic line is not presented here because the poor data quality and its peripheral location relative to the study area. However, it helps us to constrain the location of several reflectors in the northern part. These data are presently unpublished). suggests that the top of the basement is deeper northwards (from 3.5 to the South to 4.5 twt (s) to the North) (Fig.9).

\section{2-4-2)Gravity data}

In Provence more than 30000 gravity measurements are available (French Gravity Database; Grandjean et al., 1998; available on www.infoterre.brgm.fr). Field data are corrected for tidal effects, latitude, elevation and topography. The resulting complete Bouguer gravity anomaly (Fig.10a) reflects the gravity variations due to density variations within the earth's crust (Ervin, 1977), with respect to a reference density of $2.3 \mathrm{~g} . \mathrm{cm}^{-3}$. Gravity data have been interpolated with the statistical method of natural neighbours with a grid spacing of $200 \mathrm{~m}$.

Values of Bouguer gravity anomaly range from -100 to 60 mgal (Fig.10a). Since Bouguer anomalies are strongly influenced by the thickness of the continental crust, these values increase to the SW with the shallowing of the Moho depth,. In order to focus on shallower gravity disturbances, it is possible to remove this first order signal due to the influence of the crustal thickness by interpolating a trending surface that represents the regional tendency of data. A third degree polynomial trending surface has been interpolated from Bouguer anomaly data (Fig10b). This surface is consistent with the Moho isobaths (Ménard, 1979) (Fig10b). Then, this anomaly has been subtracted from the total Bouguer anomaly. The result is the residual Bouguer anomaly that highlights local gravity anomalies (Fig 10c)

Negative anomaly areas correspond to thick Cenozoic sedimentation domains, which are from east to west:

1) to the east of the MDF, the Miocene continental Valensole Basin (q in Fig. 10c);

2) to the west of the Aix fault, in the southern part, a negative anomaly corresponding to the late Cretaceous to Eocene Arc basin (p in Fig.10c);

3 ) in the southern part of the Salon-Cavaillon fault zone, the negative anomaly corresponds to an Oligo-Miocene basin (Lamanon basin; s in Fig.10c) (Oudet, 2008), probably incised by the Messinian canyon of the Durance River (Clauzon, 1979);

4) the westernmost anomaly is located along the Rhône River. It is more curvilinear than others. This anomaly corresponds to the course of the Rhône Messinian canyon ( $\mathrm{r}$ in Fig 10c). This canyon has been infilled during the Pliocene by marine marls and continental conglomerates (Clauzon, 1982). 
Positive anomaly areas correspond to uplifted zones (Alpilles, Luberon, Costes, Ventoux, Lure, Nerthe ridges) and Mesozoic calcareous plateau (Vaucluse, Languedoc) (Fig. 10c). Figure 10d represents the vertical gradient of the residual Bouguer anomaly. The vertical gradient allows us to constrain the location of the local anomaly sources. This map shows that the sources of positive anomalies are located on anticlines such as the Luberon, Alpilles, Costes, Fare, Anelier, Nerthe, Ventoux or Lure ridges. Some other positive local anomalies can be discerned to the west of the SCF, north of the Alpilles, suggesting the presence of anticlines covered by Quaternary deposits at the base of each positive anomaly. This interpretation is reinforced by the interpretation of seismic line 82SE4C (Fig 9), which provides evidence for ramp anticlines at the base of each positive gravity anomaly. Indeed, residual gravity profiles along seismic lines (Fig. 9d) show a systematic positive anomaly at the base of each anticline detected with the help of the seismic lines. The larger anomaly (between 30000 and 35000) corresponds to the Alpilles fold with an amplitude of about 5 to $7 \mathrm{mgal}$. The other folds of this profile also show gravity anomalies (amplitude of $2 \mathrm{mgal}$ for the St Rémy fold and about 5 mgal for the Caumont and Chateaurenard folds). The same types of anomalies are present along the seismic line 82SE4D (Fig.8d), at the base of the Istres fold (amplitude $\sim 5$ mgal), Anelier range (amplitude $\sim 5 \mathrm{mgal}$ ) and the Alpilles southern folds (amplitude $\sim 2$ mgal). We note that the average value of the Bouguer residual gravity anomaly is higher to the north of the profile (+5 mgal) than to the south ( -2 mgal).It may be interpreted as the result of the deepening of the basement to the South (Fig.8d).

With the help of gravity data, it is possible to interpret the lateral extension of each hidden structure detected on seismic lines to the west of the SCF, this complements the structural framework of the western Provence (Fig. 10d). The folds located to the north of the Alpilles are $\mathrm{N} 10^{\circ}$ E-trending S-verging ramp anticlines with a shallow décollement level (less than $4 \mathrm{~km}$-deep). The Istres fold is a N80 E-trending $\mathrm{N}$-verging ramp anticline with a deeper décollement level (more than $4 \mathrm{~km}$-deep).

The folds located to the North of the Alpilles ridge delimit the Miocene basins. Two hypotheses can be evoked to explain this geometry: (i) Miocene strata were deposited on a preexisting topography controlled by the folds; (ii) Miocene deposits are folded due to the formation or reactivation of the anticlines. Similarities with the Alpilles structure (same vergence and same décollement level) suggest an evolution similar to that of the Alpilles, i.e., a Miocene reactivation of pre-existing folds.

\section{3) The role of the SCF}

\section{3-2) Tectonic restoration of the SCF zone from the Eocene to the present.}

In Fig.4 and Fig.11, we have reconstructed the position of the Alpilles and Luberon ridges before the tectonic inversion of the Miocene. For the Luberon, we have restored the bend due to the drag fold deformation according to the post-Miocene shortening deduced from Miocene geomorphic and geological markers. For the Alpilles, we reported that Miocene deformation is responsible for (i) the dextral displacement along strike-slip faults that separate the eastern block from the rest of the range and (ii) a part of the shortening of the ramp anticline on the western side of the range. Therefore, to reconstruct the position of the ridge before the Miocene, we have restored the dextral displacement along these faults, and the postMiocene shortening of the ramp anticline. The reconstructed position of the two ridges is presented in Fig.4 and Fig.11.

The two escarpments located at the termination of each ridge have been formed by a normal faulting corresponding to the SCF trace during the Oligocene extension phase.(Fig. 11). 
Before the Oligocene, these two ridges were E-W folds; the orientation of the two ranges' main structures (folds and faults) being about $\mathrm{N} 90^{\circ} \mathrm{E}$-trending. Since Miocene (Langhian), the Luberon ridge has been reactivated as a S-verging ramp anticline bent as a drag fold along a dextral strike-slip fault (SCF) near its western termination. The Alpilles S-verging ramp anticline has been less developed, because a part of the deformation has been accommodated on its eastern termination by an anticlockwise rotation of $45^{\circ}$ around a vertical axis.

\section{3-1) Differences of structural styles on both sides of the SCF}

Two synthetic N-S cross-sections either side of the SCF have been drawn (Fig.12). The western one has been compiled from the two seismic profiles presented (Fig.8 and Fig.9). We used the interpretation of profile 81SE5D presented in Terrier et al. (2008) for the eastern one (Fig.12). The northern parts of the two cross-sections (the Ventoux and Lure ridges) have been compiled from balanced-crossed sections presented by Ford and Stahel (1995).

For the eastern profile, from the Luberon to La Fare ridge, interpretation by Terrier et al., (2008) provides evidence that all major structures are S-verging within the part of the NPCB included between the MDF and the SCF. The main décollement level in this part is located in the Triassic (Fig.12). The depth of décollement level is about 3 twt (s) (7800 m-deep) especially for southern ridges (Trevaresse, La Fare) (Fig.12). N-verging structures exist to the east of the MDF (e.g. Sainte Baume, Sainte Victoire) and to the West of the SCF (e.g. Istres, Anelier thrusts). This indicates that these two faults are major transfer faults. The Lure ridge is a N-verging thrust probably formed during the Pyrenean phase (Lacombe and Jolivet, 2005) and reactivated during the Alpine phase (Ford and Stahel, 1995). Lure thrust is probably connected to the southern structures by a same décollement level rooted in Triassic layers (Fig.12). The formation of these structures during the Pyrenean phase implies that the shortening is accommodated to the south by thrusts involving the basement as proposed by Lacombe and Jolivet (2005).

The western cross-section is mainly constructed thanks to the interpretation of the two seismic lines presented in this paper. It suggests that the main décollement level is rooted in Jurassic layers, at a shallower depth than to the east of the SCF (Fig.12). To the north of the Carpentras basin, the Ventoux thrust is a N-verging structure probably connected to southern structures by a same décollement level rooted in Jurassic layers (Fig.12). It is connected to Triassic layers to the south of the Istres Anticline.

The interpretation of seismic profiles confirms differences of décollement depth level between the eastern and the western side of the SCF. The décollement depth is deeper to the East than to the West and allows us to explain the difference of deformation style between the Alpilles and the Luberon. This difference of depth can be interpreted as resulting from sedimentary inheritance, which controls the thickness of the different layers and therefore the rheological properties of the thrust.

\section{4) Miocene deformation rates}

Field observations near the SCF have allowed us to constrain the age of the beginning of the Alpine compression in this area at the Burdigalian-Langhian transition (16 Ma). This age is consistent with regional tectonic studies, which suggest the beginning of the inversion by Langhian (Villeger, 1984; Baroux, 2000). In the eastern part of the Luberon, the main phase of Alpine deformation was completed just before the beginning of the Messinian salinity crisis at about $6 \mathrm{Ma}$ (Clauzon, 1984; Clauzon et al., submitted). 
Balanced cross-sections and deformation of Miocene markers allows us to quantify the Miocene deformation of the two studied ranges. Miocene shortening is about $1000 \mathrm{~m}$ in the Luberon (33\% of total shortening) and $100 \mathrm{~m}$ in the Alpilles (2.5\% of the total shortening). Miocene uplift is about $500 \mathrm{~m}$ for the Luberon and $50 \mathrm{~m}$ for the Alpilles.

The maximum cumulative deformation rates for the Alpine phase are deduced from the restoration of balanced cross-sections and the deformation of Miocene markers since the tectonic inversion at $16 \mathrm{Ma}$ to $6 \mathrm{Ma}$. For the Luberon, it is $0.1 \mathrm{~mm} / \mathrm{yr}$ for shortening and 0.03 $\mathrm{mm} / \mathrm{yr}$ for uplift. For the western Alpilles, it is $0.01 \mathrm{~mm} / \mathrm{yr}$ for shortening and $0.004 \mathrm{~mm} / \mathrm{yr}$ for uplift. The counter-clockwise rotation of the eastern block is about $45^{\circ}$. Large scale shortening can be estimated from the synthetic cross-sections (Fig.12): to the west of the SCF, the total shortening is about $11.5 \mathrm{~km}(10.85 \%)$. To the east, it is about $6.6 \mathrm{~km}(6.3 \%)$. Miocene shortening is about $2 \mathrm{~km}$ to the East (Champion et al., 2000), $30 \%$ of the total shortening. To the West, it is harder to quantify because of data paucity. We estimate a maximum shortening of $400 \mathrm{~m}$, i.e., $3.5 \%$ of the total shortening. These values are consistent with the values obtained from cross-sections of the Luberon and Alpilles anticlines. It indicates that (i) the main shortening episode occurred during the Late Cretaceous to Eocene Pyrenean phase, and that (ii) the Miocene Alpine deformation is mainly expressed between the MDF and the SCF. These two faults play a major role in the structural framework of the Provence area, especially during the Alpine tectonic phase. The NF corresponds to the westernmost limit of the Miocene deformation extension (Champion et al., 2000).

\section{5) Regional geodynamics implication}

Our results show that a large part (more than $65 \%$ ) of the total shortening across Provence occurred during Pyrenean tectonic phase, even in the western part of Provence, where $\mathrm{S}$-verging thrusts have often been considered as resulting from Alpine compression (e.g. Ford and Stahel, 1995; Champion et al., 2000; Chardon and Bellier, 2003). These S-verging structures resulting from the Pyrenean tectonic phase have been formed with a northwarddecreased shortening gradient (Tempier, 1987; Séranne, 1999; Lacombe and Jolivet, 2005). They accommodate shortening of deep-seated structure involving basement (Roure and Colletta, 1996). To the north of the Alpilles and Luberon ridges, the Vaucluse plateau comprised a rigid Cretaceous carbonate platform, weakly deformed (Ford and Stahel, 1995; Roure and Colletta, 1996, Lacombe and Jolivet, 2005). Our results show that the N-S Late Cretaceous to Eocene compression is responsible for opposite thrusting on either side of the rigid Vaucluse plateau, with the formation of N-verging Ventoux-Lure thrusts to the North and the formation of the S-verging Luberon-Alpilles thrusts to the South. Luberon and Alpilles Sverging ramp anticlines could be considered as a back-thrust of the main Ventoux-Lure Nverging thrust (Fig.1 and Fig. 12).

Our structural study shows a post-Oligocene southward displacement on both side of the $\mathrm{SCF}$, with a difference of deformation style, partly due to variable thickness of the sedimentary pile (Fig. 3). During the Alpine phase, the NF can be considered as a left-lateral strike-slip fault (Combes, 1984; Champion et al., 2000; Schlupp et al., 2001). It implies that the part included between the NF and the SCF suffered a global clockwise rotation. This rotation, proposed by Champion et al. (2000) for the entire NPCB, would only be limited to the part of the NPCB included between the NF and the SCF.

The Miocene deformation is responsible for a small part of the total shortening of the two ridges (33\% for Luberon, less than 5\% for the Alpilles). This importance of Miocene shortening on either side of the SCF implies that this fault plays a major role for the southward transfer of the Alpine deformation through the Provence domain. 
The stress responsible for the Alpine deformation in Provence results from the coeval influence of forces applied at both its extremities, i.e., in the north-east, the Alpine front push and in the southeast, the northward African plate drift. However, as the plate convergence is mainly accommodated within the northern Maghreb (Calais et al., 2002; Nocquet and Calais, 2004), this last one is indirect and mainly results from rotation of the Adriatic block. Besides these boundary forces, the influence of the mantle plume under the Massif Central can be superimposed along the western block boundary. Delacou et al. (2005) and Sue et al. (2007) using geological and seismological data and numerical modeling highlight that generalized extension within the alpine domain results from ongoing convergence between the African and European plates, collision no longer being ongoing and buoyancy-driven stresses (i.e., isostasy forces) dominating the present-day geodynamics of the Alps.

However, recent studies confirm that the SE France margin (Ligurian margin) is maintained in compression and that minor boundary force persists (Béthoux et al., 2008; Larroque et al., 2009), even if block displacements are not clearly evidenced by GPS measurements (e.g., Calais et al., 2002; Nocquet and Calais, 2004).

\section{Conclusion}

This study highlights the regional tectonic history with emphasis on the SCF. The SCF is a major fault that delimits two domains with significant differences in deformation styles. To the east of the SCF, the Alpine deformation of NPBC is accommodated by folding and dip-slip reverse faulting within E-W fold and thrust systems. By contrast, to the west, the Alpine Miocene deformation is mainly accommodated by shortening and block rotations around vertical axes (especially in the eastern part of the Alpilles ridge). In this study, we showed that this difference in deformation style is due to a difference in the depth of décollement level. This depth is deeper to the east; probably rooted in Triassic evaporites, at more than $4 \mathrm{~km}$ deep. To the west, it is rooted in Middle Jurassic or Lower Cretaceous marls, at less than $3 \mathrm{~km}$ depth. These differences result from the tectonic and sedimentary inheritance, which caused sedimentation differences within the NPCB due to differences in subsidence rates on both sides of the SCF. As a result, the SCF is a main transfer fault that accommodates a differential displacement to the South of both parts of the NPCB.

Main shortening occurred during the Late Cretaceous to Eocene Pyrenean phase. The Alpine deformation is responsible for a small part of the total shortening of the two ridges (33 $\%$ for Luberon, less than $5 \%$ for the Alpilles). Alpine shortening is much less important to the West of the SCF, providing evidence for the major transfer role of the SCF in the southward transfer of the Alpine deformation through the Provence domain.

The supposed trace of the SCF has been crossed by a seismic profile. A deepening of the basement roof is interpreted to the east of the SCF. However, there is no evidence for faulting in the sedimentary cover. It implies that the SCF is decoupled from the basement and that the geometry of the SCF is controlled by the deformation of E-tending thrusts on both sides. These differences in deformation behaviour have to be considered for present-day seismotectonic models of deformation. Indeed, recent tectonic activity has already been described near the SCF (Terrier, 1991; Molliex , 2009).

\section{Acknowledgements}

This study is a contribution to the CASHIMA project supervised by Fabrice Hollender. Stéphane Molliex benefited from a PhD scholarship funded by the CEA and the Conseil Regional PACA. BRGM, DIREN-PACA and Conseil Regional PACA funded the reprocessing of seismic lines. Midland Valley is acknowledged for providing "2DMove" for structural 
modelling. ISIS program provided SPOT images ((c) CNES). We thank Michel Sébrier and two anonymous reviewers for their fruitful comments on the manuscript and Nick Marriner for the correction of the English language. We also thank Fabrice Hollender for seismic profile edition, Georges Clauzon for fruitful field trips and discussions, Vincent Godard and Philippe Dussouillez for assistance in gravity processing and Pierre Guignard for discussions.

\section{References cited}

Amorèse, D., Lagarde, J.-L., Baroux, E., Font, M., Santoire, J.-P., 2009. Accurate analysis of the distribution of epicenters in Western Provence and Eastern Languedoc (Southern France). Journal of Geodynamics 47, 1, 20-29.

Arthaud, F., Matte, P., 1975. Les décrochements tardi-hercyniens du sud-ouest de l'Europe. Géometrie et essai de recontitution des conditions de la déformation. Tectonophysics 25, 139-171.

Baize S., Cushing, E.M., Lemeille, F., Granier, T., Grellet, B., Carbon, D., Combes, P. Hibsch, C., 2002. Inventaire des indices de rupture affectant le Quaternaire en relation avec les grandes structures connues en France métropolitaine et dans les régions limitrophes. Mém. Soc. Géol. Fr. 175, 142 pp.

Baroux, E., 2000. Tectonique active en région à sismicité modérée : le cas de la Provence (France). Apport d'une approche pluridisciplinaire. PhD thesis. Univ. Paris Sud, Orsay, $327 \mathrm{pp}$.

Baroux, E., Béthoux, N., Bellier, O., 2001. Analyses of the stress field in southeastern France from earthquake focal mechanisms. Geophysical Journal International 145, 336-348.

Baudrimont, A.F., Dubois, P., 1977. Un bassin mésogéen du domaine péri-alpin : le sud-est de la France. Bull. Centre Rech. Explor. Prod. Elf-Aquitaine 1, 1, 261-308.

Benedicto, A., 1996. Modèles tectono-sédimentaires de bassins en extension et style structural de la marge passive du golfe du Lion (partie Nord), SE France. PhD Thesis, Univ. Montpellier, $249 \mathrm{pp}$.

Benedicto, A., Labaume, P., Séguret, M., Séranne, M., 1996. Low-angle crustal ramp and basin geometry in the Gulf of Lion passive margin: Oligocene-Aquitanian Vistrenque graben, SE France. Tectonics 15(6), 1192-1212.

Bergerat, F., 1987. Stress field in the European platform at the time of Africa-Eurasia collision. Tectonics 6, 99-132.

Bertrand, M., 1899. La grande nappe de recouvrement de la Basse Provence. Bulletin du Service de la Carte Géologique de France X, 68, 397-467.

Besson, D., 2005. Architecture du bassin rhodano-provençal miocène (Alpes, SE France). Relations entre déformation, physiographie et sédimentation dans un bassin molassique d'avant-pays. PhD thesis, Ecole des Mines, Paris, 438 pp.

Besson, D., Parize, O., Rubino, J.-L., Aguilar, J.-P., Aubry, M.-P., Beaudoin, B., Berggren, W. A., Clauzon, G., Crumeyrolle, P., Dexcoté, Y., Fiet, N., Iaccarino, S., Jimenez-Moreno, G., Laporte-Galaa, C., Michaux, J., von Salis, K., Suc, J.-P., Reynaud, J.-Y., Wernli, R., 2005. Un réseau fluviatile d'âge Burdigalien terminal dans le Sud-Est de la France : remplissage, extension, âge, implications. C. R. Géosciences 337, 1045-1054.

Bethoux, N., Tric, E., Chéry, J., Beslier, M.-O., 2008. Why is the Ligurian Basin (Mediterranean Sea) seismogenic? Thermomechanical modeling of a reactivated passive margin. Tectonics 27, TC5011, doi: 10.1029/2007TC002232.

Blès, J.L., Gros, Y., 1991. Stress field changes in the Rhône Valley from the Miocene to the present. Tectonophysics 194, 265-277.

Boyer, S. E., Elliott, D., 1982. The geometry of thrust systems. AAPG Bull. 66, 1196-1230. 
Calais, E., Nocquet, J.M., Jouanne, F., Tardy, M., 2002. Current strain regime in the Western Alps from continuous Global Positioning System measurements, 1996-2001. Geology 30, 651-654.

Calassou, S., Larroque, C., Malavieille, J., 1993. Transfer zones of deformation in thrust wedges : an experimental study. Tectonophysics 22,1 325-344.

Catzigras, F., Colomb, E., Gervais, J., Gouvernet, C., L'Homer, A., Masse, J.-P., Rousset, C., Roux, M., 1975. Carte géologique de la France à 1/50000. Eyguières sheet, BRGM, Orléans.

Catzigras, F., Durand, J-P, Gervais, J., Gouvernet, C., Masse, J.-P., Rousset, C., Triat, J.-M., Truc, G., 1977. Carte géologique de la France à 1/50000. Chateaurenard sheet, BRGM, Orléans.

Champagnac, J.-D., Sue, C., Delacou, B., Burkhard, M., 2004. Brittle deformation in the inner NW Alps: from early orogen-parallel extrusion to late orogen-perpendicular collapse. Terra Nova 16(4), 232-242.

Champion, C., Choukroune, P., Clauzon, G., 2000. La déformation post-Miocène en Provence occidentale. Geodinamica Acta 13, 67-85.

Chantraine, J., Autran, A., Cavelier, C., 1996. Geological map of France (1/1.000.000). BRGM eds, Orléans.

Chardon, D., Bellier, O., 2003. Geological boundary conditions of the 1909 Lambesc (Provence, France) earthquake: structure and evolution of the Trévaresse ridge anticline. Bull. Soc. Geol. Fr. 174(5), 497-510.

Chardon, D., Hermitte, D., Nguyen, F. and Bellier, O., 2005. First paleoseismological constraints on the strongest earthquake in France (Provence) in the twentieth century. Geology 33(11), 901-904.

Clauzon, G., 1979. Le canyon messinien de la Durance (Provence, France) : une preuve paléogéographique du bassin profond de dessication. Palaeogeogr., Palaeoclimatol., Palaeoecol. 29, 15-40.

Clauzon, G., 1982. Le canyon messinien du Rhône: une preuve décisive du « desiccated deep basin model » (Hsü, Cita et Ryan, 1973). Bull. Soc. Géol. Fr 24, 231-246.

Clauzon G., 1984. Evolution géodynamique d'une montagne provençale et de son Piémont : l'exemple du Lubéron (Vaucluse, France). Montagnes et Piémonts, Toulouse, R.G.P.S.O.

Clauzon, G., 1996. Limites de séquences et évolution géodynamique. Géomorphologie 1, 3-22.

Clauzon, G., Fleury, J., Bellier, O., Molliex, S., Mocochain, L., Aguilar, J-P. (submitted). Tectonics and morphogenesis of Provence since the Miocene: a morphostructural study of the Luberon (SE France). Submitted to Bull. Soc. Géol. Fr.

Colletta, B., Letouzey, J., Pinedo, R., Ballard, J.F., Balé, P., 1991. Computerized X-ray tomography analysis of sandbox models: Examples of thin-skinned thrust systems. Geology 19, 1063-1067.

Combes, P., 1984. La tectonique récente de la Provence occidentale : microtectonique, caractéristiques dynamiques et cinématiques. Méthdologie de zonation tectonique et relation avec la sismicité. PhD thesis, Univ. Louis Pasteur, Strasbourg, $182 \mathrm{pp}$.

Combes, P., Carbon, D., Cushing, M., Granier, T., Vaskou, P., 1993. Mise en évidence d'un paléoséisme pléistocène supérieur dans la vallée du Rhône : implications sur les connaissances de la sismicité en France. C. R. Acad. Sc. Paris 317(Série II), 689-696.

Corroy, G., Tempier, C., Durand, J.P., 1964. Evolution tectonique de la montagne SainteVictoire en Provence. C. R. Acad. Sci. Fr. 258(D), 1556-1557.

Cushing, E. M., Bellier, O., Nechtschein, S., Sébrier, M., Lomax, A., Volant, P., Dervin, P., Guignard, P., Bove, L., 2008. A multidisciplinary study of a slow-dipping fault for 
seismic hazard assessment. The exemple of the Middle Durance Fault (SE France). Geophys. J. Int. 172, 1163-1178.

Dahlstrom, C. D. A., 1969. Balanced cross-sections. Can. J. Earth Sci. 6, 743-757.

Debrand-Passard, S., Courbouleix, S., Lienhart, M.-J., 1984. Synthèse géologique du Sud-Est de la France. Mém. BRGM 125 and 126, 615 pp.

DeCelles, P.G., Giles, K.A., 1996. Foreland basin systems. Basin Research 8, 105-123.

De Graciansky, P.C., Lemoine, M., 1988. Early Cretaceous extensional tectonics in the southwestern French Alps : a consequence of North Atlantic rifting during Tethyan spreading. Bull. Soc. Géol. de France (8), IV, 5, 733-737.

Delacou, B., Sue, C., Champagnac, J.-D., Burkhard, M., 2005. Origin of the current stress field in the Western/Central Alps: role of gravitational re-equilibration constrained by numerical modeling. Geol. Soc. London, Spec. Publ. 243, 295-310.

Demarcq, G. 1970. Étude stratigraphique du Miocène rhodanien. Mém. BRGM 61, 257 pp.

Dercourt J., Zonenshain, L.P., Ricou, L.E., Kasmin, V.G., Le Pichon, X., Knippe,r A.L., Grandjacquet, C., Sbortshikov, I.M., Geyssant, J., Lepvrier, C., Pechersky, D.H., Boulin, J., Sibuet, J.C., Savostin, L.A., Sorokhtin, O., Westphal, M., Bazhenov, M.L., Lavez, J.P., Biju-Duval, B., 1986. Geological evolution of the Tethys belt from Atlantic to Pamirs since the Lias. Tectonophysics 123, 241-315.

Dewey, J., Helman, M., Turco, E., Hutton, D., Knott, S., 1989. Kinematics of the western Mediterranean. In : Alpine tectonics, M. Coward, D. Dietrich and G. Parks (eds), Geol. Soc. Spec. Publ. 45, 265-283.

Dutour, A., Philip, H., Jaurand, E., Combes, P., 2002. Mise en évidence de déformations en faille inverse avec ruptures de surface cosismiques dans des dépôts colluviaux würmiens du versant nord du Mont Ventoux (Provence occidentale, France). C. R. Géoscience 334, 849-856.

Elliott, D., 1983. The construction of balanced cross sections. J. Struct. Geol. 5 (2), 101.

Ervin, P.C., 1977, Theory of the Bouguer anomaly. Geophysics 42, 1468.

Fitzgerald, P. G., Munoz, J. A., Coney P. J., Baldwin, S.L., 1999. Asymmetric exhumation across the Central Pyrenees: Implications for the tectonic evolution of a collisional orogen. Earth Planet. Sci. Lett. 173, 157- 170.

Ford, M., Stahel, U., 1995. The geometry of a deformed carbonate slope-basin transition: The Ventoux-Lure fault zone, SE France. Tectonics 14, 5, 1393-1410.

Gattacceca J., Deino, A., Rizzo, R., Jones, D.S., Henry, B., Beaudoin, B., Vadeboin, F., 2007. Miocene rotation of Sardinia: New paleomagnetic and geochronological constraints and geodynamic implications. Earth Planet. Sc. Lett. 258, 359-377.

Germain, C., Liouville, M., de Bouchony, P., Roch, E., Demarcq, G., 1966. Carte géologique de la France à 1/50000. Cavaillon sheet, BRGM, Orléans.

Gignoux, M., 1925. Géologie stratigraphique. Masson et Cie, Paris.

Goguel, J., 1932. Description géologique du Luberon. Bull. Serv. Carte Geol. Fr. XXXII, 186, $1-74$.

Goguel, J., 1944. Description géologique des Alpilles. Bull. Carte Geol. Fr. XLIV, 214, 1-28.

Gouvernet, C., Gueirard, S., Catzigras, F., Colomb, E., Gervais, J., Blanc, J.-P., Busser, T., Grégoire, J.-Y., Lambert, C., Rouire, J., 1968. Carte géologique de la France à 1/50000. Salon-de-Provence sheet, BRGM, Orléans.

Grandjean, G., Ménnechet C., Debéglia N., Bonijoly D., 1998, Insuring the quality of gravity data, EOS Trans. American Geophysical Union 79, 217-221.

Guieu, G., 1968. Un exemple de tectonique tangentielle : l'évolution du cadre montagneux de Marseille. Bull. Soc. Géol. Fr. 7, 610-630. 
Guignard, P., Bellier, O., Chardon, D., 2005. Géométrie et cinématique post-oligocène des failles d'Aix et de la moyenne Durance (Provence, France). C. R. Géosciences 337, 375-384.

Haug, E., 1925. Les nappes de charriages de la Basse Provence, $1^{\circ}$ partie. Mém. Serv. Carte Géol. Fr., 304 pp.

Hibsch, C., Kandel, D., Montenat, C., Ott D'Estevou, P., 1992. Evénements tectoniques crétacés dans la partie méridionale du bassin subalpin (massif de Ventoux-Lure et partie orientale de l'arc de Castellane, SE de la France). Implications géodynamiques. Bull. Soc. géol. Fr. 163, 2, 147-158.

Hippolyte, J.-C., Dumont, T., 2000. Identification of Quaternary thrusts, folds and faults in a low seismicity area: examples in the Southern Alps (France). Terra Nova 12, 156-162.

Hippolyte, J.-C., Nury, D., Angelier, J., Bergerat, F., 1991. Relation entre tectonique extensive et sédimentation continentale : exemple des bassins oligocènes de Marseille et de Basse-Provence. Bull. Soc. Géol. Fr. 162(6), 1083-1094.

Hippolyte, J.-C., Angelier, J., Nury, D., Bergerat, F., Guieu, G., 1993. Tectonic-stratigraphic record of paleostress time changes in the Oligocene basins of the Provence, southern France. Tectonophysics 226, 15-35.

Lacombe, O., Jolivet, L., 2005. Structural and kinematic relationships between Corsica and the Pyrenees-Provence domain at the time of the Pyrenean orogeny. Tectonics 24, TC1003, doi : 10.1029/2004TC001673.

Lambert, I., Levret-Albaret, A., Cushing, M., Durouchoux, C., 1996. Mille Ans de Séismes en France, Ouest Eds., Paris.

Larroque, C., Delouis, B., Godel, B., Nocquet, J.-M., 2009. Active deformation at the southwestern Alps - Ligurian basin junction (France-Italy boundary): Evidence for recent change from compression to extension in the Argentera massif. Tectonophysics $467,1-4,22-34$.

Leleu, S., Ghienne, J.-F., Manatschal, G., 2009. Alluvial fan development and morpho-tectonic evolution in response to contractional fault reactivation (Late Cretaceous-Paleocene), Provence, France. Basin Research 21(2), 157-187.

Lemoine, M., 1984 : La marge occidentale de la Téthys ligure. In : Les marges continentales actuelles et fossiles autour de la France. Boillot G. (eds), Masson, Paris, part. 3, 157248.

Lemoine, M., Trümpy, R., 1987. Pre-oceanic rifting in the Alps. Tectonophysics 133, 305-320.

Le Pichon, X., Bergerat, F., Roulet, M.J., 1988. Plate kinematics and tectonics leading to the Alpine belt formation; a new analysis. Geol. Soc. Am. Spec. Pap. 218, 111-131.

Levret, A., Backe, J.C., Cushing, M., 1994. Atlas of macroseismic maps for French earthquakes with their principal characteristics. Natural Hazards, 10(1-2), 19-46.

Masse, J.P., Villeneuve, M., Leonforte, L., Nizou, J., 2009. Block tilting of the North Provence early Cretaceous carbonate margin: stratigraphic, sedimentologic and tectonic data. Bull. Soc. Geol. Fr. 180, 2, 105-115.

Mattauer, M., 1968. Les traits structuraux essentiels de la chaîne Pyrénéenne, Rev. Geol. Dyn. Geogr. Phys. 10, 3-11.

Mauffret, A., Gorini, C., 1996. Structural style and geodynamic evolution of Camargue and Western Provençal basin, southeastern France. Tectonics 15, 356-375.

Ménard, G., 1979. Relations entre structures profondes et structures superficielles dans le S.E. de la France. Essai d'utilisation des données géophysiques. PhD thesis, Univ. Joseph Fourier, Grenoble.

Ménard, G., 1980. Profondeur du socle antétriasique dans le Sud-Est de la France., C. R. Acad. Sc. Paris 290, 299-302. 
Molliex, S., 2009. Caractérisation de la déformation récente en Provence (SE France). PhD thesis, Univ. Aix-Marseille III, 350 pp.

Nocquet, J.-M., Calais, E., 2004. Geodetic measurements of crustal deformation in the western mediterranean and Europe. Pure and Applied Geophysics 161, DOI 10.1007/s00024003-2468-z.

Oudet, J., 2008. Etude terre-mer de la transition syn-rift/post-rift sur les marges de l'océan Liguro-Provençal. PhD thesis, Univ. Aix-Marseille I., 288 pp.

Philip, J., Masse, J-P., Machnour, L., 1987 : L'évolution paléogéographique et structurale du front de chevauchement nord-toulonnais (Basse Provence occidentale, France). Bull. Soc. Geol. Fr. 8(III), 3, 541-550.

Ramsay, J.G., Huber, M., 2007. The Techniques of Modern Structural Geology, volume 2: Folds and Fractures, Academic Press, London.

REGINE group (Groupe de Réflexion Géologie de l'Ingénieur et Néotectonique), Blès, J.L., Colleau, A., Fourniguet, J., Godefroy, P., Lenôtre, N., Sauret, B., Combes, P., Dubié, J.Y., Vaskou, P., 1991. Proposal for classification of fault activity in an intraplaque collision setting: Definitions and examples. Tectonophysics 194, 279-293.

Réhault, J.P., Boillot, G.,Mauffret, A., 1984. The western Mediterranean basin geological evolution. Marine Geology 55, 447-477.

Ritz, J.-F., 1991. Evolution du champ de contraintes dans les Alpes du sud depuis la fin de l'Oligocène. Implications sismotectoniques. PhD thesis, Univ. Montpellier II, 187 pp.

Roca, E., Sans, M., Cabrera, L., Marzo, M., 1999. Oligocene to Middle Miocene evolution of the central Catalan margin (northwestern Mediterranean). Tectonophysics 315, 209-229.

Rosenbaum, G., Lister, G.S., Duboz, C., 2002. Relative motions of Africa, Iberia and Europe during Alpine orogeny. Tectonophysics 359, 117-129.

Roure, F., Colletta, B., 1996. Cenozoic inversion structures in the forland of the Pyreneen and the Alps. In Ziegler, P.A., Horvath, F. (eds), Peri-Tethys memoir 2: Structure and prospects of Alpine Basins and Forelands. Mém. Mus. Natn. Hist. Nat. 170, 173-209.

Roure, F., Choukroune, P., 1998. Contribution of the Ecors seismic data to the Pyrenean geology: Crustal architecture and geodynamic evolution of the Pyrenees, Mem. Soc. Geol. Fr. 173, 37- 52.

Rousset, C., 1974. Le chevauchement nord-provençal en bordure de la vallée du Rhône : la klippe de Mouriès. C. R. Acad. Sc. Paris 279, 647-650.

Rousset, C., 1975. Apport de la méthode rétro-tectonique à la connaissance de la paléogéographie régionale: l'exemple des bauxites de Provence. C. R. Acad. Sc. Paris 281, 375- 378.

Rousset, C., 1978. De l'importance régionale de la faille d'Aix-en-Provence. C. R. Acad. Sc. Paris 286, série D, 189-192.

Schlupp, A., Clauzon, G., J-P. Avouac, 2001. Mouvement post messinien sur la faille de Nîmes : implications pour la sismotectonique de la Provence. Bull. Soc. Géol. Fr. 7(172), 697711.

Sébrier, M., Ghafiri, A. and Blès, J.-L., 1997. Paleoseismicity in France: Fault trench studies in a region of moderate seismicity. Journal of Geodynamics 24(1-4), 207-217.

Séranne, M., 1999. The Gulf of Lion continental margin (NW Mediterranean) revisited by IBS: an overview. In: L.J. B. Durant, F. Horvath and M. Séranne. (Editor), The Mediterranean Basins: Tertiary Extension within the Alpine Orogen. London: Geological Society, 15-36.

Shaw, J. H., Bilotti, F., Brennan, P.A., 1999. Patterns of imbricate thrusting. Geol. Soc. Am. Bull. 111, 1140-1154.

Sibuet, J-C., Srivastava, S., Spakman, W., 2004. Pyrenean orogeny and plate kinematics. J. Geophys. Res. 109, B08104, doi : 10.1029/2003JB002514. 
Stampfli, G. M., Borel, G.D., 2002. A plate tectonic model for the Paleozoic and Mesozoic constrained by dynamic plate boundaries and restored synthetic oceanic isochrones. Earth Planet. Sci. Lett. 196, 17-33.

Sue, C., Delacou, B., Champagnac, J. D., Allanic, C., Tricart, P., Burkhard, M., 2007. Extensional neotectonics around the bend of the Western/central Alps: an overview. Int. J. Earth Sci. (Geol. Rundsch), DOI 10.1007/s00531-007-0181-3.

Tempier, C., 1987. Modèle nouveau de mise en place des structures provençales. Bull. Soc. Géol. Fr. 8(3), 533-540.

Terrier, M., Lenôtre, N., 1989. Reconnaissance néotectonique d'un accident majeur en Provence (France) : utilisation de la comparaison des nivellements et de l'analyse morphostructurale. Bull. AFEQ 3, 161-170.

Terrier, M., 1991. Néotectonique de la Provence occidentale (France) : vers une analyse multicritère des déformations récentes. Application à la classification des structures sismogènes. PhD thesis, Univ. Aix-Marseille 1, Doc. BRGM 207, 232 pp.

Terrier, M., Serrano, O., Hanot, F., 2008. Reassessment of the structural framework of western Provence (France): consequence on the regional seismotectonic model. Geodynamica acta 21(5-6), 231-238.

Villeger, M., 1984. Evolution tectonique du panneau de couverture Nord-Provençal (MontVentoux, Luberon, Moyenne Durance). PhD thesis, Univ. Paris-Sud, 175 pp.

Villeger, M., Andrieux, J., 1987. Phases tectoniques post-Eocènes et structuration polyphasée du panneau de couverture nord provençal (Alpes externes méridionales). Bull. Soc. geol. Fr. 8, 147-156.

Woodward, N.B., Boyer, S.E., Suppe, J., 1985. An Outline of Balanced Cross Sections, 2nd ed., Stud. Geol., vol. 11. Dep. of Geol., Univ. of Tenn., Knoxville.

Ziegler, P.A., 1992. European Cenozoic rift system. Tectonophysics 208, 91-111.

\section{Figures captions}

Figure 1 : Location and structural setting of the study area (modified after Chardon and Bellier, 2003). a) The red frame represents the area of Fig. 2. The red line corresponds to the trace of profile line of Figs. 8 and 9. AA' and BB' represent the trace of the synthetic cross-sections presented on Fig. 12.

Figure 2 : Thickness of the sedimentary cover of western Provence (after Ménard, 1980), highlighting the control of the SCF system on sedimentation and fold and thrust development. The white lines correspond to the trace of the seismic profiles presented on Figs. 8 and 9.

Figure 3 : Comparison of the stratigraphic succession for Alpilles and Luberon. Note the strong differences of subsidence rate during Jurassic and Early Cretaceous times.

Figure 4 : Structural sketch of Salon-Cavaillon fault and surrounding area modified after Germain et al. (1966); Gouvernet et al.(1968); Catzigras et al. (1975; 1977). aa' and bb' indicates the location of balanced cross sections respectively of Fig. 6 and 5. Black-and-white dashed lines correspond to the position of the block boundaries prior to Miocene deformation. Note that the two main escarpments near the SCF lines up before Miocene deformation.

Figure 5 : Balanced cross-section of the Luberon ridge and restoration at the top of the Barremian series. Location in Fig 4. 
Figure 6 : Balanced cross-section of the Alpilles ridge and restoration at the top of the Barremian series. Location on Fig.4.

Figure $7:$ a) Aerial view of one fault of the dextral strike-slip fault system which separates the eastern and western parts of the Alpilles range. b) Unconformity between Miocene and Late Cretaceous to the north of the Alpilles range. c) Miocene marine abrasion surface deformed by reverse faulting in the Luberon range.

Figure 8 : Seismic line 82SE4D, A) Topographic profile B) seismic traces, C) interpretation, and D) residual gravity profile (from data in fig.10). Location on Figs. 1 and 2.

Figure 9 : Seismic line 82SE4C, A) topographic profile, B) seismic traces, C) interpretation and D) residual gravity profile (data from fig.10). Location in Figs. 1 and 2.

Figure 10 : Gravity map of western Provence. A) Map of Bouguer anomaly. B) First order Bouguer anomaly and comparison with Moho isodepths from Chantraine et al. (1996) (white lines). C) Map of residual Bouguer anomaly (second order). Positive values are correlated with anticlines whereas negative values are correlated with Tertiary basins. a: NF, b:SCF, c: MDF; d: Luberon, e: Alpilles, f: Anelier, g: Costes, h: Trevaresse, i: La Fare, j: Aix-Eguilles thrust, k: Nerthe, 1: Ste Victoire, m: Ste Baume, n: Lure, o: Ventoux, p: Arc Basin, q: Valensole basin, r: Rhône Messinian valley, s: Lamanon graben D) Vertical gradient of residual Bouguer anomaly. Dashed lines correspond to new structures detected in this study: t: Caumont anticline; u: Chateaurenard anticline; v: St Remy anticline; w: Istres anticline.

Figure 11 : Block diagrams representing the morphostructural context of the SCF zone during the Cenozoic. The Pyrenean phase (Late Cretaceous to Middle Eocene) is responsible for the formation of Alpilles and Luberon S-verging folds and thrusts. The two fold terminations are cut by the SCF during the extensional Oligocene phase. The two ridges did not evolve simultaneously during Miocene compressional phase; the deformation in the Luberon is accommodated by the propagation of a S-Verging ramp anticline, bent as a drag fold near the SCF. The deformation in the Alpilles is mainly accommodated by the counterclockwise rotation of its eastern termination.

Figure 12: Interpretative N-S cross-sections on either sides of the SCF. Location on figure 1. AA' section is interpreted from Ford and Stahel (1995); Lacombe and Jolivet (2005) and Terrier et al. (2008). Section BB' is interpreted from Ford and Stahel (1995) and this study. 


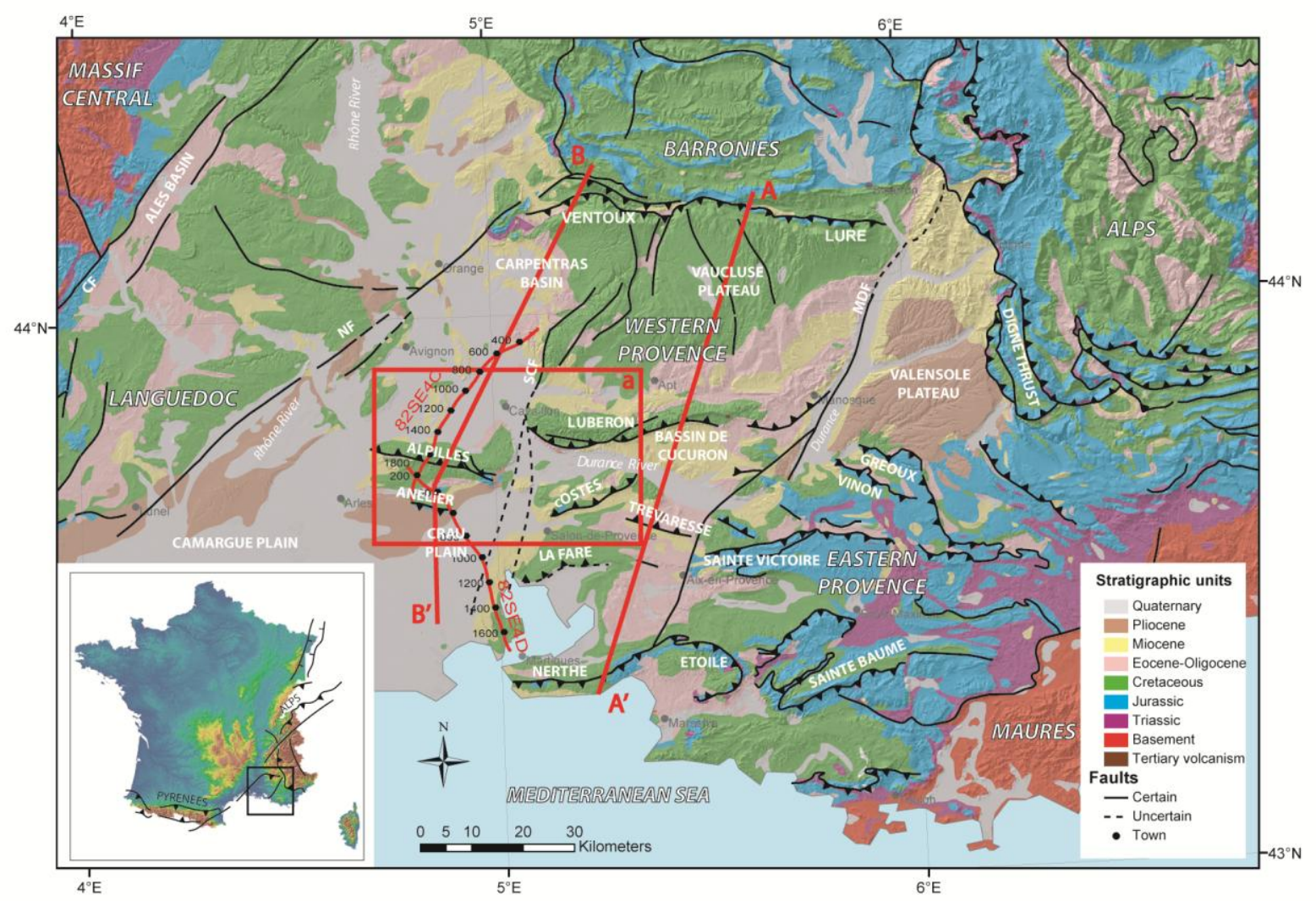

Figure 1 


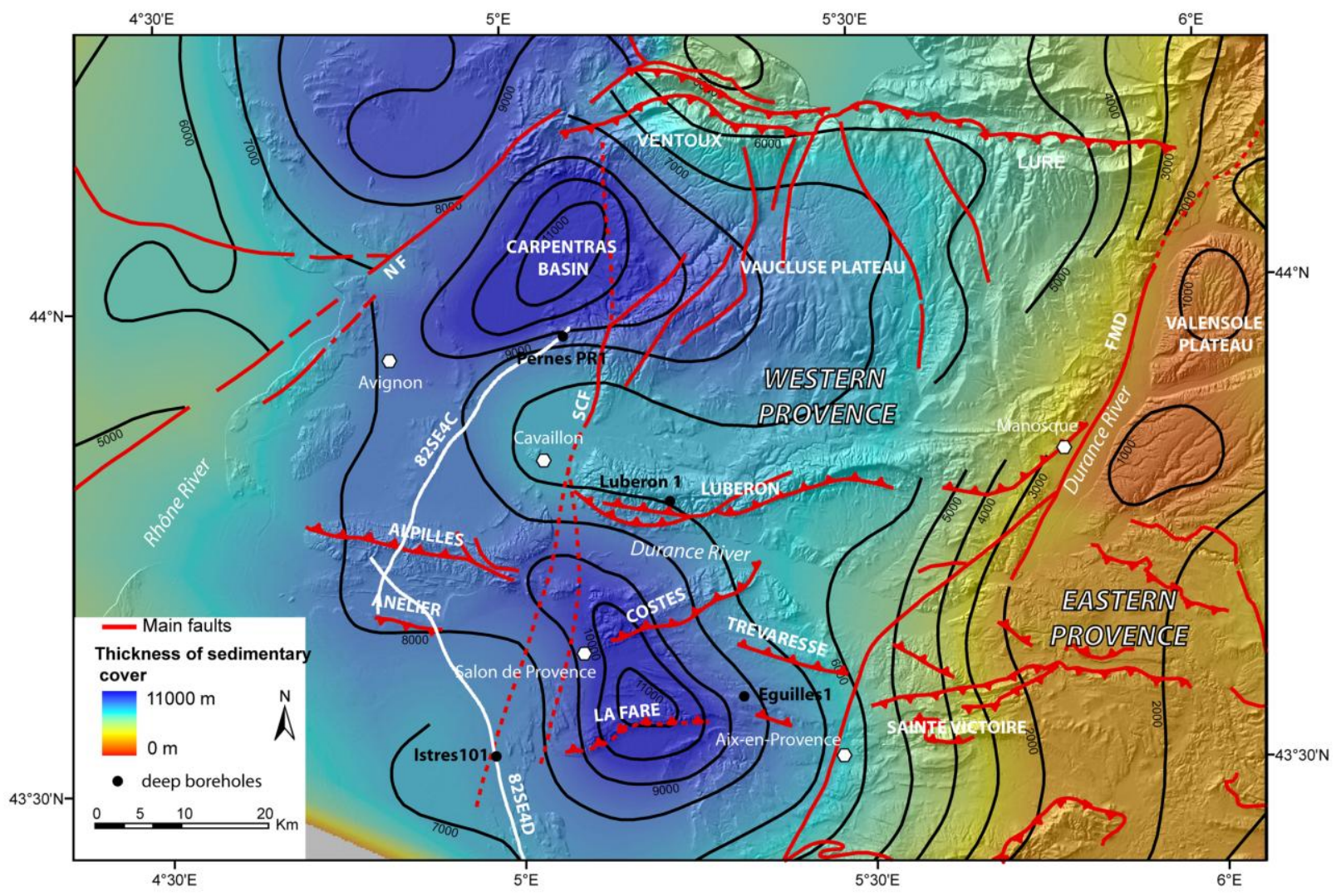

Figure 2 


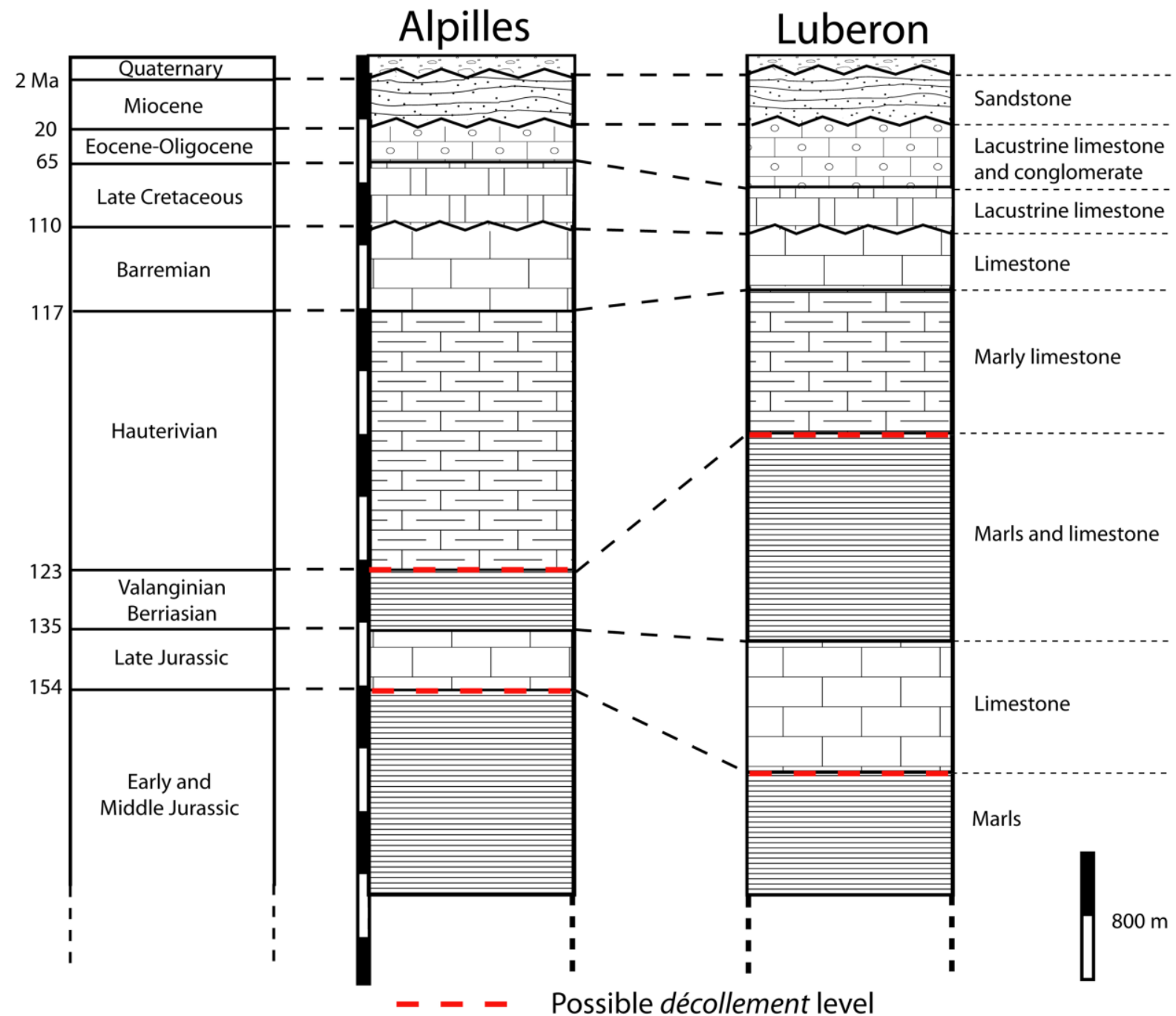

Figure 3 

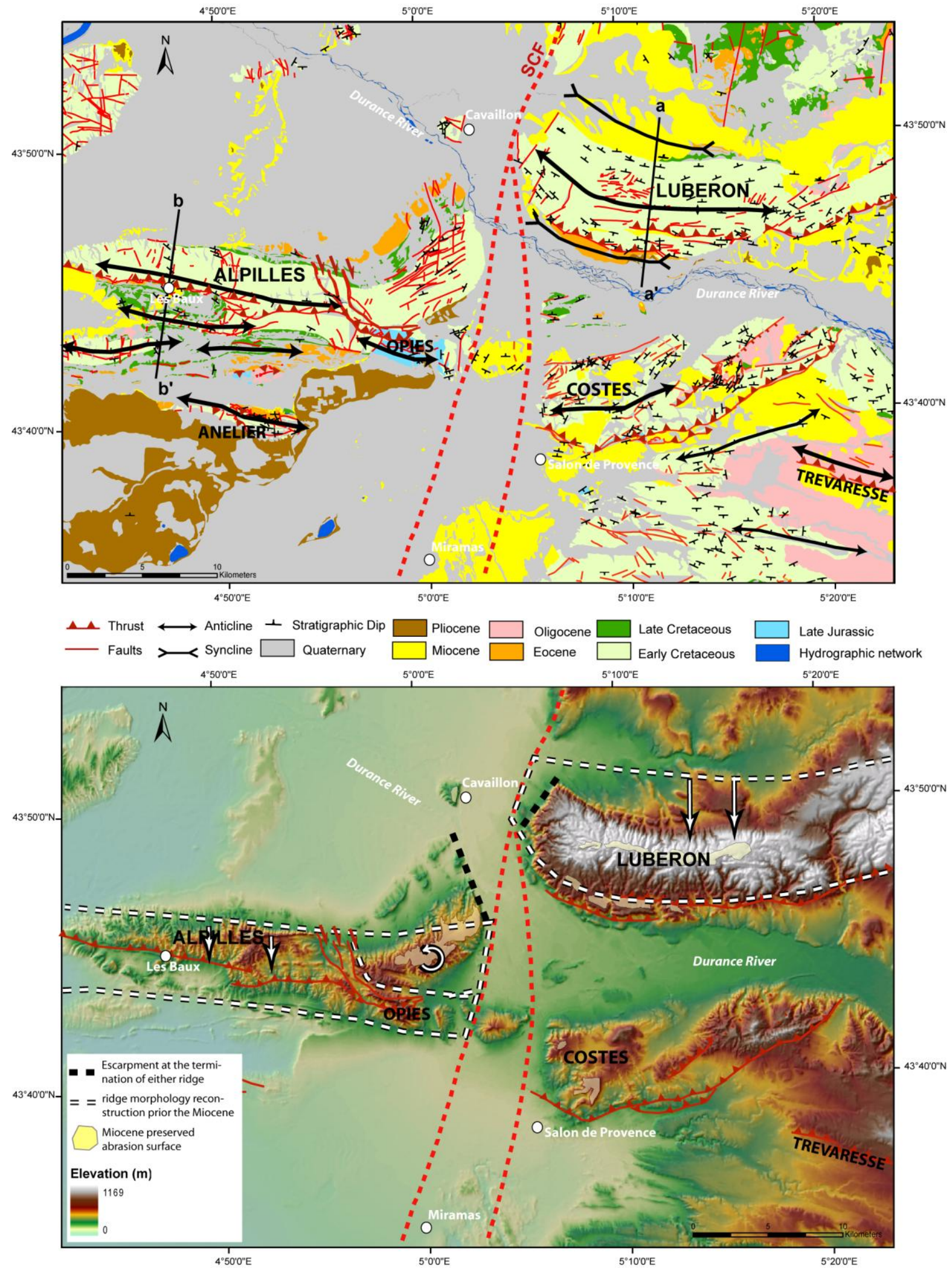

Figure 4 


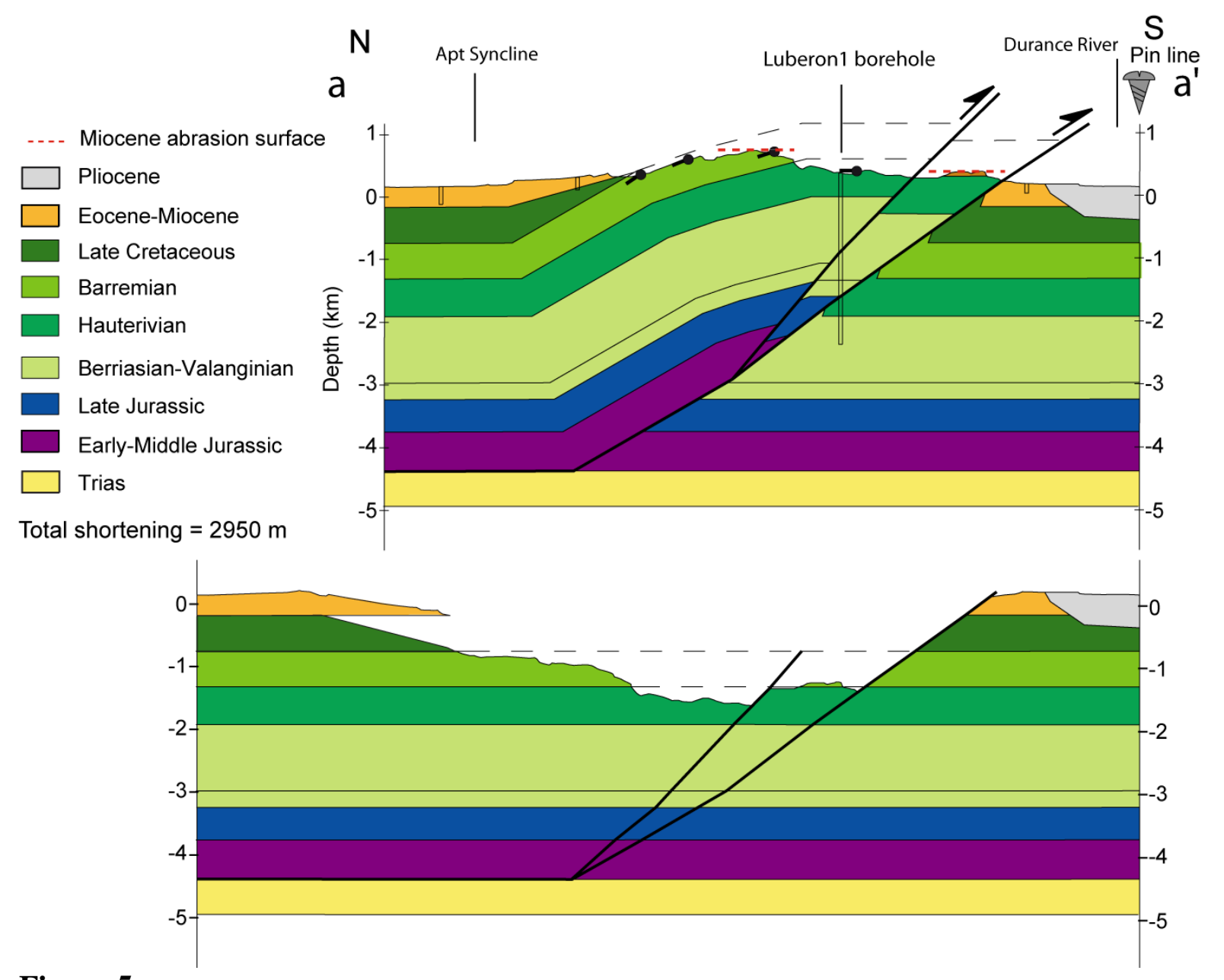

Figure 5 


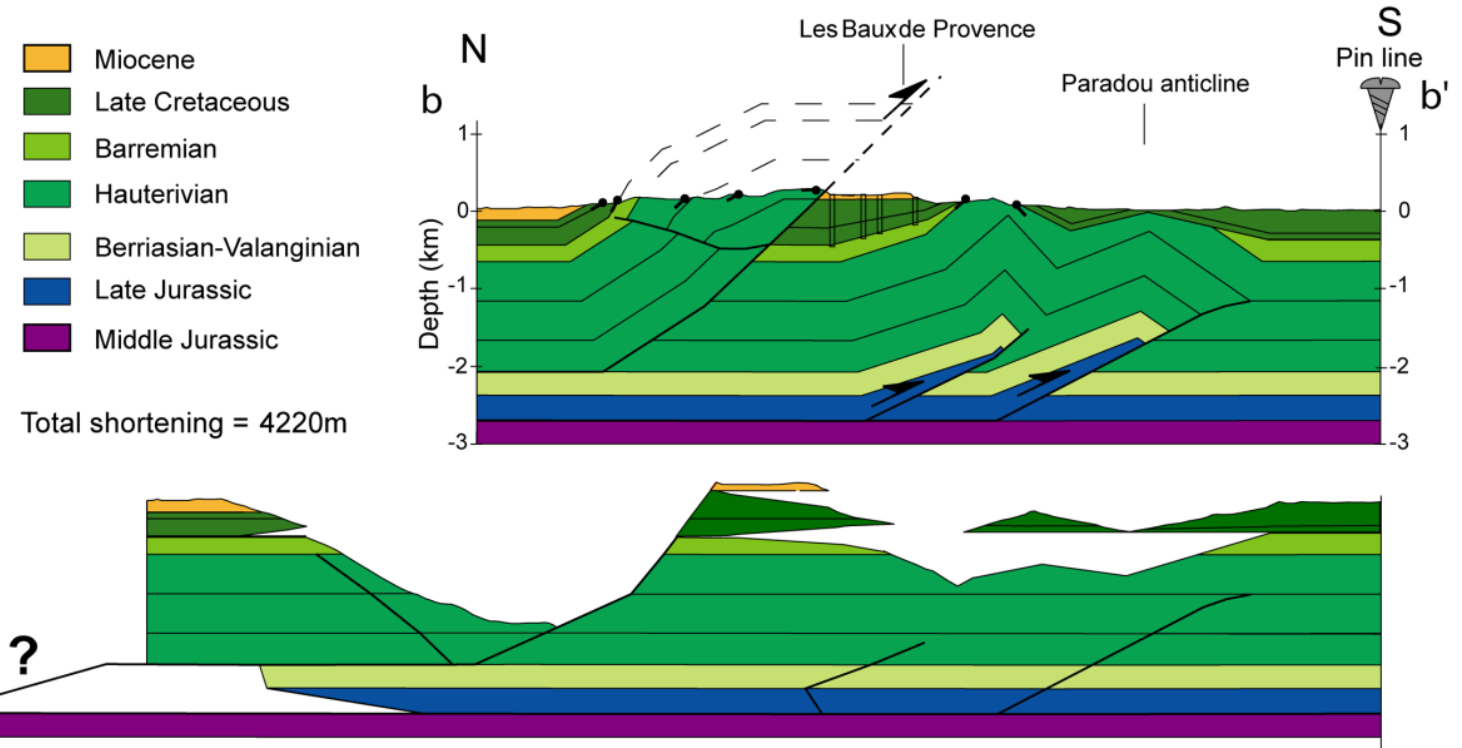

Figure 6 


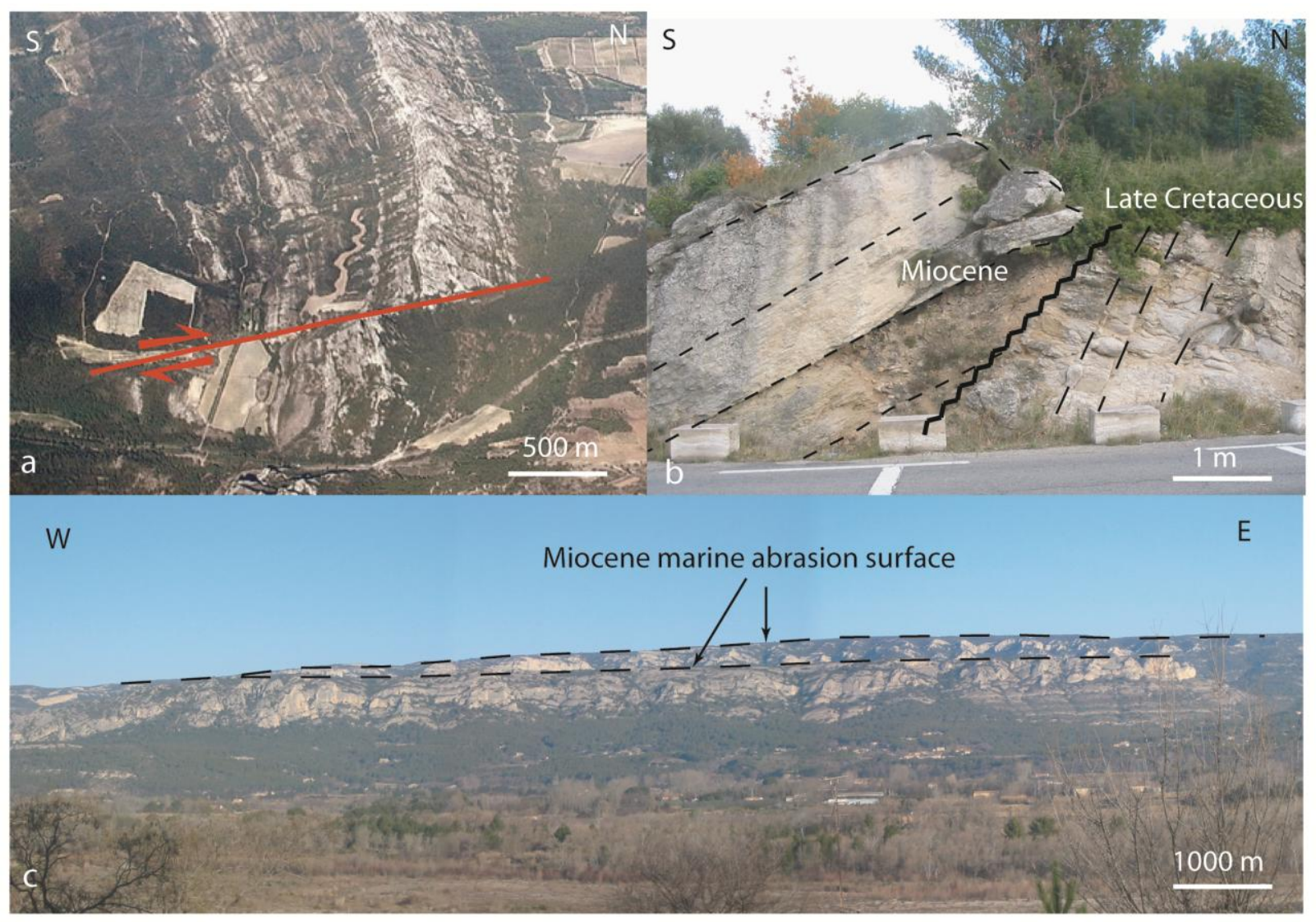

Figure 7 

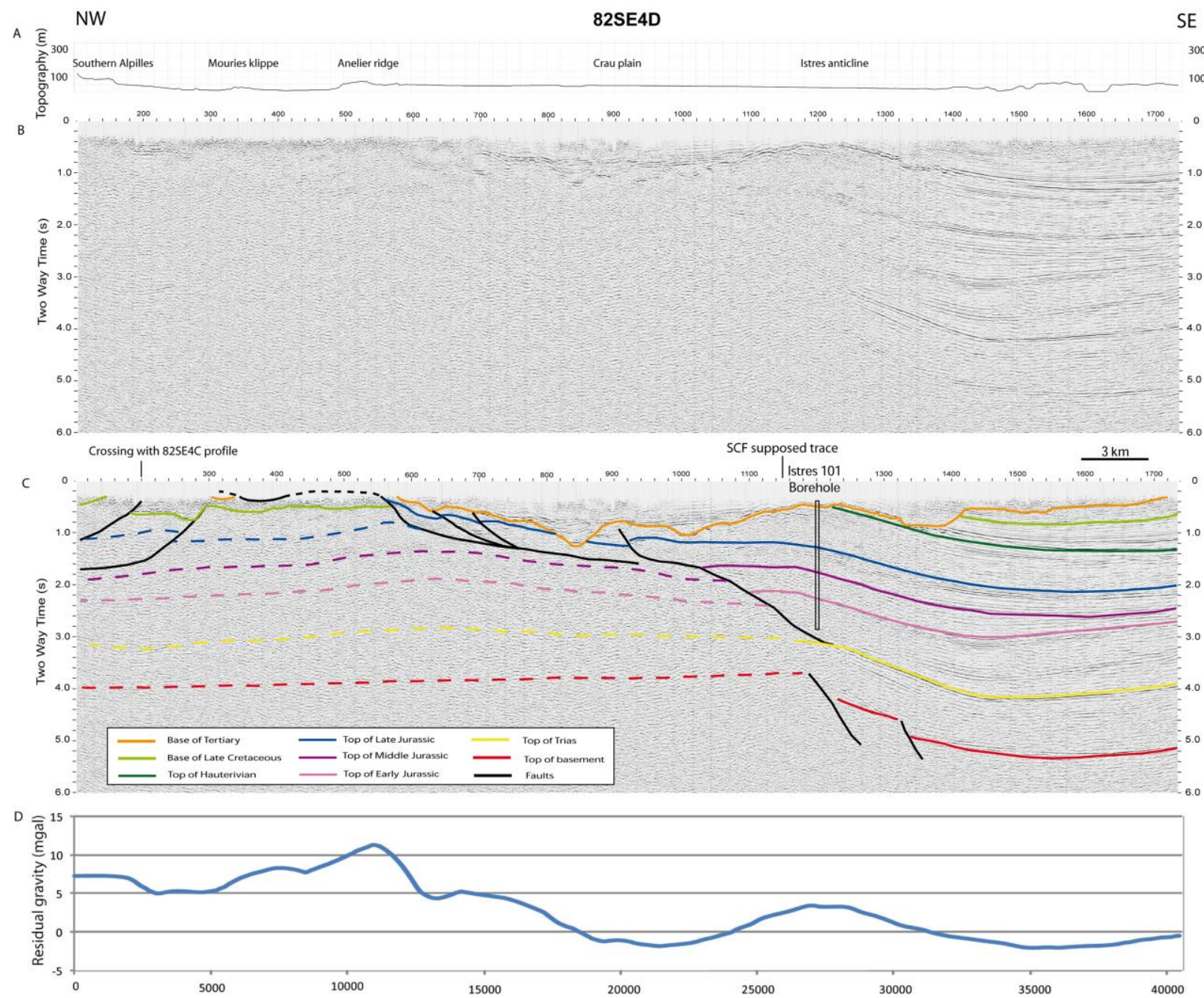

Figure 8 

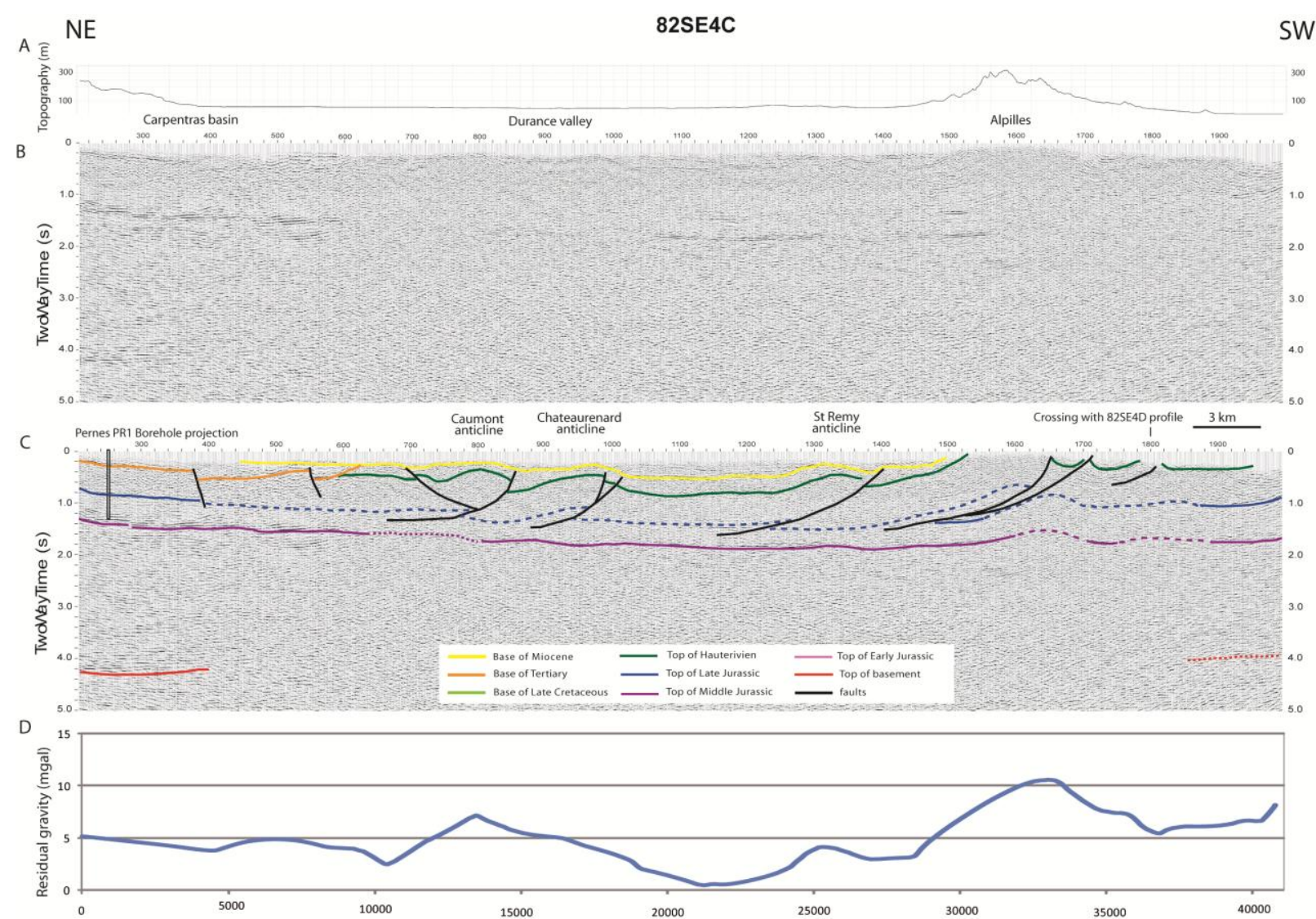

Figure 9 

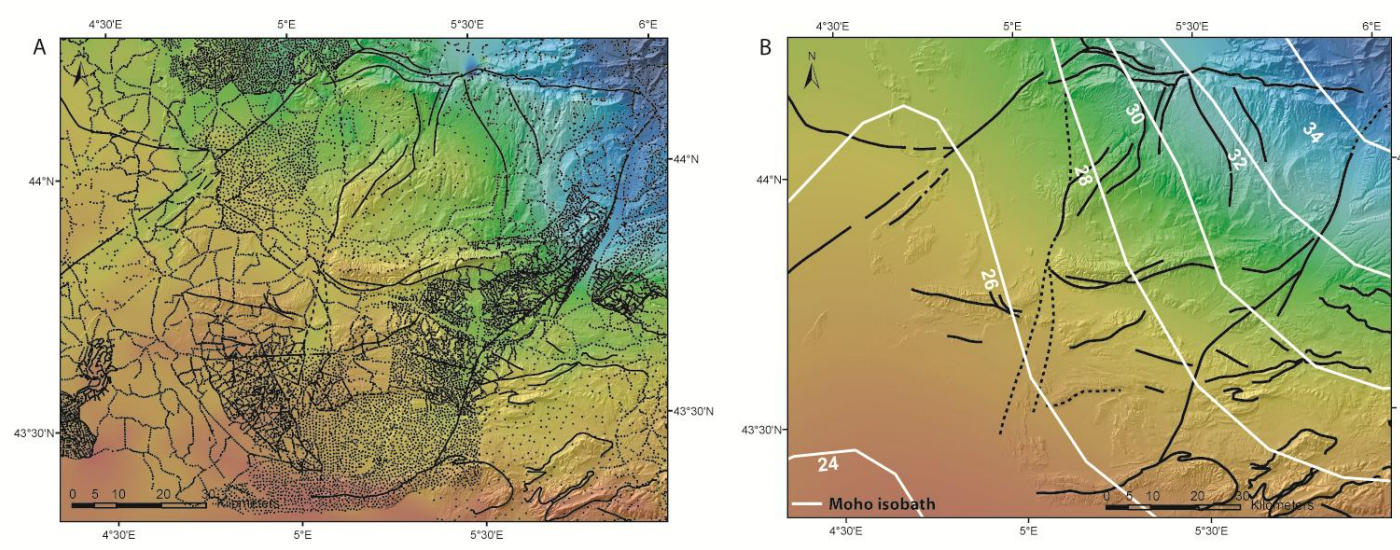

FAULTS

- Certain .num." New

- Gravity station Bouguer anomaly (mgal)

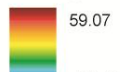

$1^{\circ}$ order Bougue $1^{\circ}$ order Bouguer anomaly trending
surface (mgal)
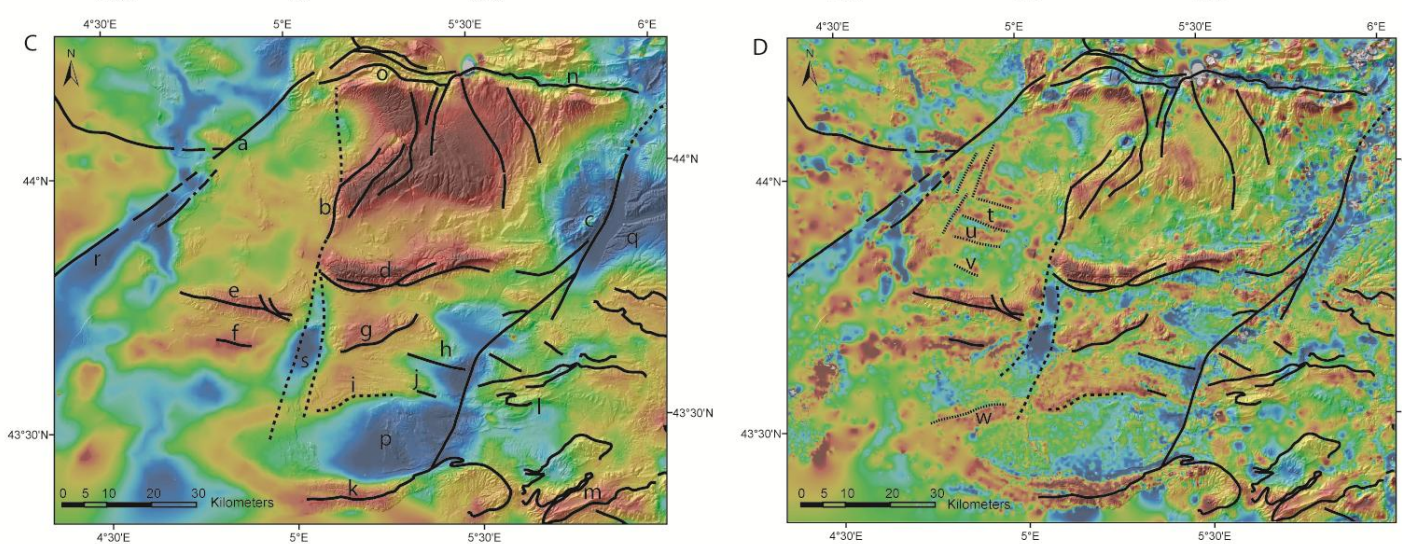

77.34

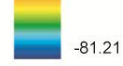

Residual Bouguer anomaly (mgal)

\subsection{8

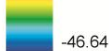

Vertical gradient of residual Bouguer anomaly (mgal/m)

0.033
-0.045

\section{Figure 10}




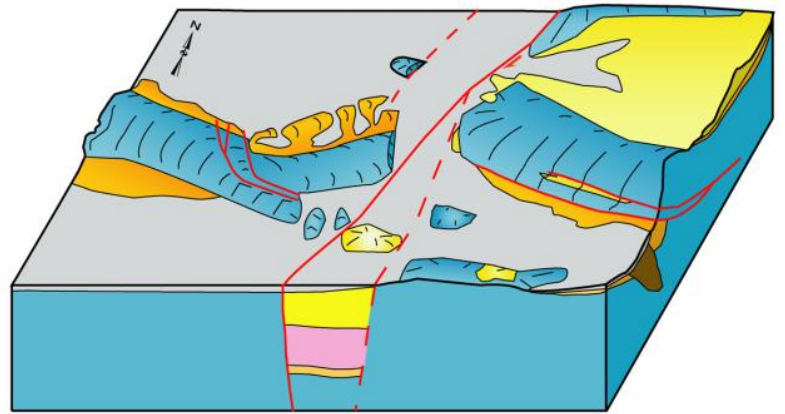

Present

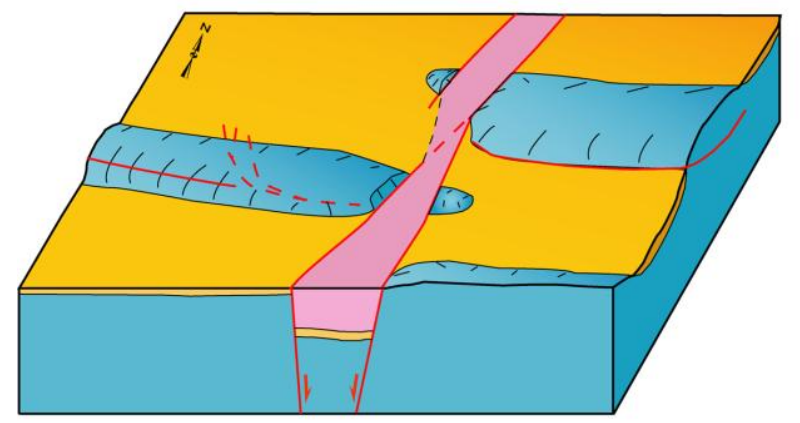

Late Oligocene (25 My)

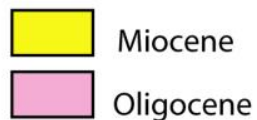

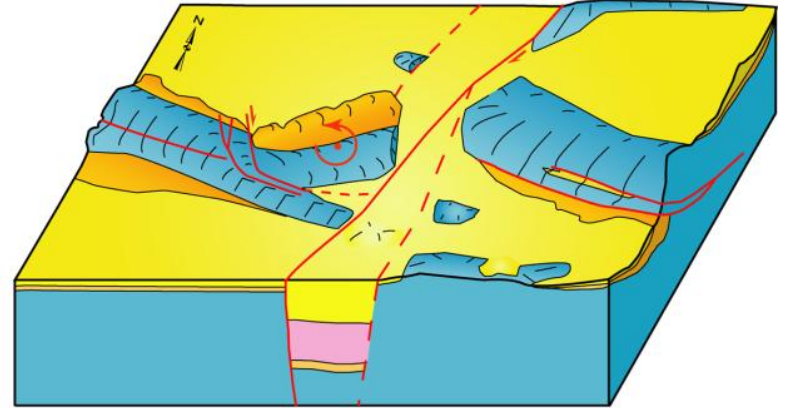

Late Miocene (6 My)

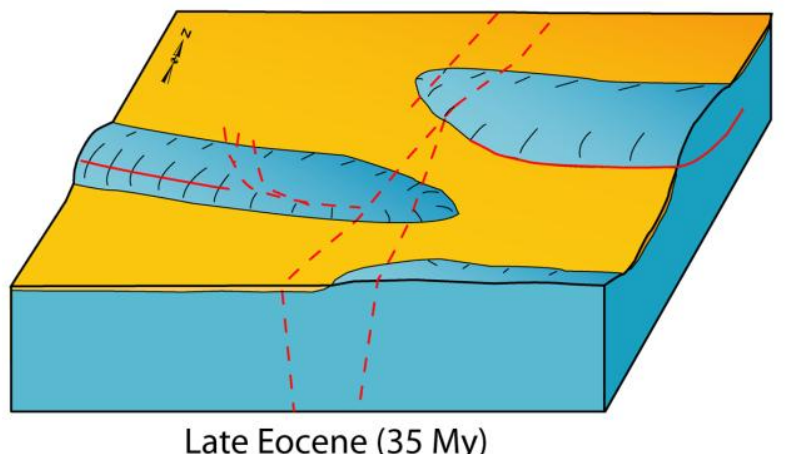

Upper-Cretaceous. - Eocene

Jurassic - Lower-Cretaceous Faults

\section{Figure 11}




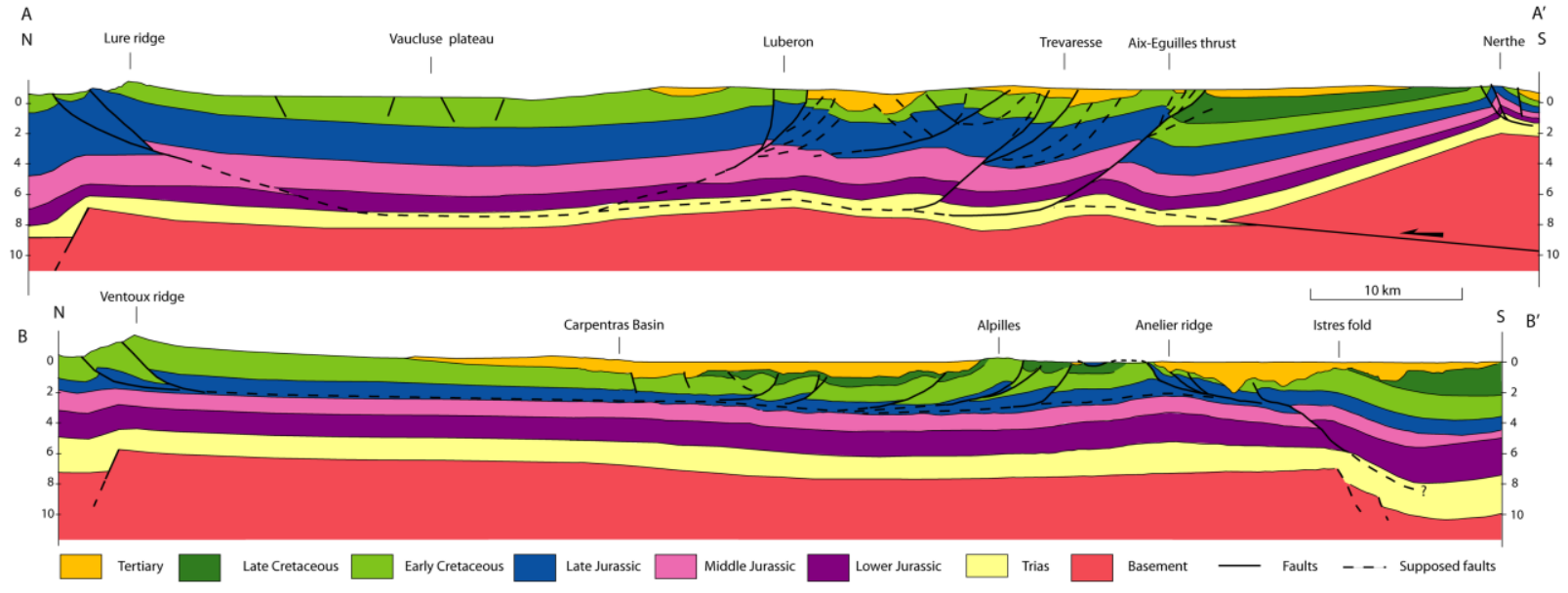

Figure 12 